IBAD, 2020; (7): 1-18

\title{
Ankara'da Ulaşım Sistemlerinin Altında Kalan Dereler: Bentderesi Örneği
}

\author{
Mehtap Yılmaz ${ }^{1 *}$ \\ Prof. Dr. Özge Yalçıner Ercoşkun²
}

Gelis tarihi: 21.12.2019

Kabul tarihi: 09.01.2020

\section{Atıf bilgisi: \\ IBAD Sosyal Bilimler Dergisi \\ Sayı: $7 \quad$ Sayfa: $1-18$}

Yıl: 2020 Dönem: Yaz

This article was checked by Turnitin. Similarity Index 5\%

${ }^{1}$ Gazi Üniversitesi, Türkiye, mehtapyilmaz95@gmail.com ORCID ID 0000-0002-0660-0547

2 Gazi Üniversitesi, Türkiye, ozgeyal@gmail.com

ORCID ID 0000-0003-2734-0374

* Sorumlu yazar öz

Ankara dereleri Cumhuriyet Döneminden günümüze kadar olan süreçte hızlı nüfus artışı ile birlikte ulaşım ve altyapı hizmetlerine olan taleplerin artması doğrultusunda yok edilmiştir. Cumhuriyetin ilk yıllarında, köylerden kente göçler artmış ve dereler etrafinda hızla gecekondular yayılmıştır. Artan altyapı ihtiyacı karşılanamayınca evsel ve sanayi atıkları derelere verilmeye başlanmış ve dereler açık kanalizasyon hatları haline gelmiştir. $\mathrm{Bu}$ duruma bir çözüm üretilememiş ve dereler beton menfezler içine alınmıştır. Günümüzde trafik ve altyapı ihtiyacı bu derelere gömülü durumdadır ve dereler trafiği taşıyan kanallara dönüştürülmüştür. Yoğun kentsel yapılaşma ile derelerin günümüzde, kentin hangi güzergâhında ilerlediklerini tespit etmek güç durumdadır. Fakat doğal yatağı bozulan derelerin bazılarının isimleri caddelere verilmiştir. Geçmişte beton menfezler içerisine alınan dereler, günümüzde ulaşım altyapısı ve üstyapısını tehdit etmektedir. Bu nedenle menfezler içinde akan derelerin ne durumda olduğunu tahmin etmek imkânsızdır. Günümüzde Ankara genelindeki yollarda, altgeçitlerde, katlı kavșaklarda, bazı kamu kuruluşlarında ve metro istasyonlarında meydana gelen seller tesadüfi değildir. Ankara kentinde ulaşım ve çevre ilişkisi iyi kurgulanamamış, eş zamanlı olarak birbirine zarar veren iki kavram haline dönüştürülmüştür. Ankara'nın kayıp derelerinin keşfedilmesi, tekrar gün yüzüne çıkarılması ve bugünkü ulaşım sistemleri ile birlikte düşünülerek dere restorasyon projelerinin gerçekleștirilmesi gerekmektedir. Bu araștırmanın asıl amacı ise ulaşım sistemleri için Ankara'nın doğal değeri olan derelerinin yok edilişini ortaya koymak ve Ankara'nın üzeri kapatılan ilk deresi olan Bentderesi'nin geçmişteki ve bugünkü kullanımlarını çevreye olan etkileriyle karşılaştırmaktır. $\mathrm{Bu}$ karşılaştırmada arşiv kaynaklarına başvurulmuş, Ankara'nın şehir planları ve haritaları, eski fotoğraf arşivleri, gazete haberleri ve hava fotoğrafları kullanılarak derenin bugünkü durumu tartışılmış ve öneriler sunulmuştur.

Anahtar Kelimeler: Ankara'nın Dereleri, Bentderesi Caddesi, Ankara Su Taşkınları, Nehir Restorasyon Projesi. 


\title{
Streams under Transportation Systems in Ankara: Example of Bentderesi
}

\author{
Mehtap Yilmaz ${ }^{1 *}$ \\ Prof. Dr. Özge Yalçiner Ercoşkun²
}

First received: 21.12 .2019

Accepted: 09.01.2020

\section{Citation:}

IBAD Journal of Social Sciences

Issue: $7 \quad$ Pages: $1-18$

Year: $2020 \quad$ Session: Summer

This article was checked by Turnitin. Similarity Index 5\%

\section{${ }^{1}$ Gazi University, Turkey, mehtapyilmaz95@gmail.com} ORCID ID 0000-0002-0660-0547

${ }^{2}$ Gazi University, Turkey, ozgeyal@gmail.com

ORCID ID 0000-0003-2734-0374

* Corresponding Author

\begin{abstract}
Ankara streams have been destroyed in line with the rapid increase in population in the period from the Republican era to the increasing demand for transportation and infrastructure services. In the early years of the Republic, migrations from villages to cities increased and shantytowns spread rapidly around streams. When the increasing infrastructure needs could not be met, domestic and industrial wastes were started to be given to streams and streams became open sewer lines. A solution to this situation could not be produced and the streams were enclosed in concrete culverts. Today, the need for traffic and infrastructure is embedded in these streams; streams have been converted into channels carrying traffic. With the intense urbanization, it is difficult to determine the course of the streams. However, some of the streams whose natural bed is deteriorated are given to the streets. In the past, the streams, which were taken into concrete culverts, today threaten the transportation infrastructure and superstructure, and it is impossible to predict how the streams flowing through the culverts. Nowadays, the floods in Ankara roads, underpasses, crossroads, some public institutions and subway stations are not accidental. The relationship between transportation and environment in Ankara has not been well established and has been transformed into two concepts that harm each other simultaneously. The lost streams of Ankara should be discovered, unearthed again and stream restoration projects should be realized with today's transportation systems. The main purpose of this study is to reveal the destruction of Ankara's natural streams for transportation systems and to compare the past and present uses of Bent Stream, which is the first covered stream of Ankara, with the effects on the environment. In this comparison, the sources of the archives were used, the current situation of the stream was discussed and suggestions were made using the city plans and maps of Ankara, old photograph archives, newspaper news and aerial photographs.
\end{abstract}

Kew Words: Ankara's Streams, Bentderesi Street, Ankara Floods, River Restoration Project. 


\section{GİRIŞ}

Kentler iç içe geçmiş doğal ve sosyo-ekonomik sistemlerden meydana gelmektedir. Her bir sistemin kaynağı diğer sistemlerin kaynaklarına bağlı olarak sürekli değişmekte ve kent sistemini oluşturmaktadır. Hızlı nüfus artışı ve yapılaşma ile artan çevresel kirlilik, iklim değişikliği ve küresel isınma kentlerin doğal sistemi olan ekosistemlere zarar vermektedir. Bu sebeple ekosisteme verilen zararın en aza indirilmesi, ekolojik denge ve çeșitliliğinin korunması yönünde çözümler geliștirilmektedir. Bu çözümlerden biri de kentsel yeşil alt yapı sistemleridir. "Kentsel yeşil altyapı, ekosistem değerlerini ve işlevlerini koruyan, ekosistem hizmetlerini sunmak için tasarlanan ve yönetilen, birbirleriyle bağlantılı doğal, yarı-doğal ve kültürel alanların oluşturduğu bir yeşil alan ağıdır. Kentsel yeşil altyapı, doğa tabanlı çözümlerle birlikte iklim değişikliğinin olumsuz etkileriyle mücadelede kentlerin dayanıklılığını arttırmada önemli bir araçtı"' (Tapan Şilliler ve Ceviz Sanalan, 2013, s. 4). Bir diğer ifadeyle ise kentsel yeşil altyapı; birbirine bağlı su yolları, sulak alanlar, orman alanları, vahşi yaşam habitatları, yeşil alanlar, parklar, koruma alanları, çiftlikler, ormanlar ve tüm doğal ekolojik süreçlerin sürdürülmesine imkan tanıyan, hava ve su kaynaklarını koruyup doğal yaşamı destekleyen açı alan sistemidir (Benedict ve McMahon, 2002, s. 12). Yeşil altyapı alanları Tablo 1'de görüldüğü üzere merkez (çekirdek), bağ (koridor) ve alan olmak üzere üç bileşenden oluşmaktadır (Demir ve Baylan, 2019, s. 81).

\begin{tabular}{|c|c|c|}
\hline Merkez (Çekirdek) & Bağlantı/Bağ (Koridor) & Alan (Leke) \\
\hline $\begin{array}{ll}\text { - } & \text { Doğal rezerv alanlar } \\
\text { - } & \text { Mezarlıklar } \\
\text { - } & \text { Vahşsi yaşam alanları } \\
\text { - } & \text { Sulak alanlar } \\
\text { - } & \text { Büyük ölçekli parklar } \\
\text { - } & \text { Çiftlikler } \\
\text { - } & \text { Bölgesel ve ulusal parklar }\end{array}$ & $\begin{array}{l}\text { - Akarsular } \\
\text { - Nehir yatakları } \\
\text { - } \text { Yollar } \\
\text { - Eneri hatları } \\
\text { - Drenaj yolları } \\
\text { - Kanallar } \\
\text { - Parklar }\end{array}$ & $\begin{array}{ll}\text { - } & \text { Boş araziler } \\
\text { - } & \text { Yerleşim alanları } \\
\text { - } & \text { Sanayi Alanları } \\
\text { - } & \text { Atık imha alanları } \\
\text { - Karma kullanım bölgeleri } \\
\text { - } & \text { Ticaret alanları } \\
\text { - } & \text { Yeşil çatılar }\end{array}$ \\
\hline
\end{tabular}

Tablo 1: Kentsel Yeşil Altyapı Bileşenlerine Örnekler (Demir ve Baylan, 2019, s. 81)

Kentsel yeşil altyapı planlaması ise parsel ölçeğinden bölgesel ölçeğe kadar farklı ölçeklerde hazırlanabilmektedir. Kentsel yeşil altyapı planlaması, arazi kullanım planlarının geliştirilmesinde ilk adım olmalı; yollar, kanalizasyon, su hatları ve diğer temel gri altyapı ile koordine edilmelidir. Daha etkili entegre planlama ve tasarım, ekonomik ve sürdürülebilir bir ağda yeşil ve gri arasında bağlantı kurmalıdır (Benedict ve McMahon, 2002, s. 12). Kentsel yeşil altyapının bir bileşeni olan yeşil koridorlar, kentin tüm yeşil sistemini birbirine bağlar ve anlamlı hale getirir. Kentsel mavi koridorlar ise temiz su sağlama, deşarj ve sıcaklığı ayarlama, yeraltı suyu kaynaklarını iyileştirme, biyolojik çeşitliliği destekleme ve estetik, eğlence ve kültürel değerleri koruma gibi birçok çevresel ve sosyal amaca hizmet eder (Chou, 2016, s. 2). Kent ekosisteminin destekleyicisi ve tamamlayıcisı olan yeşil ve mavi koridorlar; ekolojik dengenin kurulması ve sürdürülebilir kentlerin oluşturulmasına katkı sağlamak amacıyla yeşil altyapının bir parçası olarak planlanmalıdır.

Avrupa'da ve başka yerlerde, su yollarının aşırı kullanımı, habitat koşullarının bozulmasına, biyolojik çeşitliliğin azalmasına, temiz su temini ve kirleticilerin giderilmesi gibi ekosistem hizmetlerinin bozulmasına neden olmuştur (Leporı, Palm, and Malmqvist, 2005, s. 229). Bu hizmetlerin sürdürülmesi konusundaki endişeler, nehir restorasyon çabalarına teşvik etmiştir (Palmer ve diğerleri, 2005, s. 209). Nehir restorasyon çalışmaları ekolojik değerlerin korunması ve ekosistem hizmetlerinin çalışır hale gelmesi için bir firsat olarak görülmelidir. Bir nehir restorasyon çalışmasının ekolojik olarak başarılı sayılması için Palmer ve diğerleri (2005, s. 210-212) aşağıdaki beş kriteri sağlaması gerektiğini belirtmişlerdir;

-muhtemel olarak tanımlanan ve restorasyona rehberlik eden dinamik bir uç nokta olarak "yol gösterici bir görüntü” üretir,

-ekosistemlerin ve nehrin ekolojik koşulları ölçülebilir şekilde iyileştirir,

-nehir ekosisteminin restorasyon öncesine göre daha fazla kendi kendini sürdürmesi için

uyarlanabilir kapasite arttırır,

-restorasyon tarafindan kalıcı bir zarar verilmez,

-proje öncesi ve sonrası değerlendirme yapılır ve bilgiler paylaşılır. 
$\mathrm{Bu}$ kriterlerin benimsenmesi ile iklim değişikli, hızla artan küresel ısınma ve çevresel kirlilik ile mücadelede doğal dereler ve yatakları etkin ve verimli kullanılmış olacaktır. Sürdürülebilir çevre yönetimi ve taşkınların önlenmesi için uluslararası alanda çok fonksiyonlu nehir gelişmeleri desteklenmektedir (Chou, 2016, s. 1). Kentlerde yapılaşmanın en yaygın etkileri arasında derelerin beton menfezler ve kanallar içine alınması ve kanalizasyon atıkları ile kirletilmesi yer almaktadır. Bununla birlikte, suyu yeraltı menfezlerine yönlendirmek sorunludur, çünkü drenaj kapasitesini sınırlar, akış aşağısında sel riskini arttırır, su ekosistemlerine zarar verir, su kalitesini düşürür ve su alanını insanlar için görünmez kılar (Chou, 2016, s. 2). Dereler, yeniden kentsel yeşil altyapının bir bileşeni olarak çok işlevli açık alanlar haline nehir restorasyon projeleri ile dönüştürülmelidir. Böylece sürdürülebilir su yönetimi sağlanırken ekolojik bütünlük de korunacaktır.

Günümüzde su duyarlı kent planlama yaklaşımı ile kentler yeniden tasarlanmaya başlanmıştır. Geçmişte üzeri kapatılıp ulaşım sistemlerinin altında kalan nehirler için nehir restorasyon projeleri uygulanmaktadır. Örneğin 2005 Y1lında Güney Kore'deki Seul kentinde Cheonggyecheon Deresi restorasyonu gerçekleștirilmiştir (Şekil 1). "Güney Kore'nin başkenti Seul'de yer alan proje, dünyanın en büyük kentsel tasarım projelerinden biri olarak nitelendirilmektedir. 1940'larda üzeri betonla kapatılarak otoyola dönüştürülen Cheonggyecheon nehri, kenti ikiye bölmekle birlikte otoyol altlarında güvensiz bölgelerin de oluşumuna neden olmuştur" (Kırkık Aydemir, Yılmazsoy ve Turgay, 2018, s. 34). 5.9 km'lik büyük üst geçidin kaldırılması, Seul şehir merkezinin görsel olarak ve fiziksel olarak dikey erişilebilirliğini geliştirmiştir. Beton kütlenin ortadan kalkmasıyla şehrin görsel koridoru açılmış ve Cheonggyecheon Deresi'ndeki 22 köprü şehir alanının kuzey ve güney taraflarını birbirine bağlamışır (Ryu and Kwon, 2016, s. 14). Proje sayesinde su kalitesi ve akıntıları yönetilmiş, kentin bulunduğu havza ve kentsel alanlar yeniden canlandırılmış, yerel vatandaşların yeşil alanlara ve su izine erişimi sağlanmıştır.
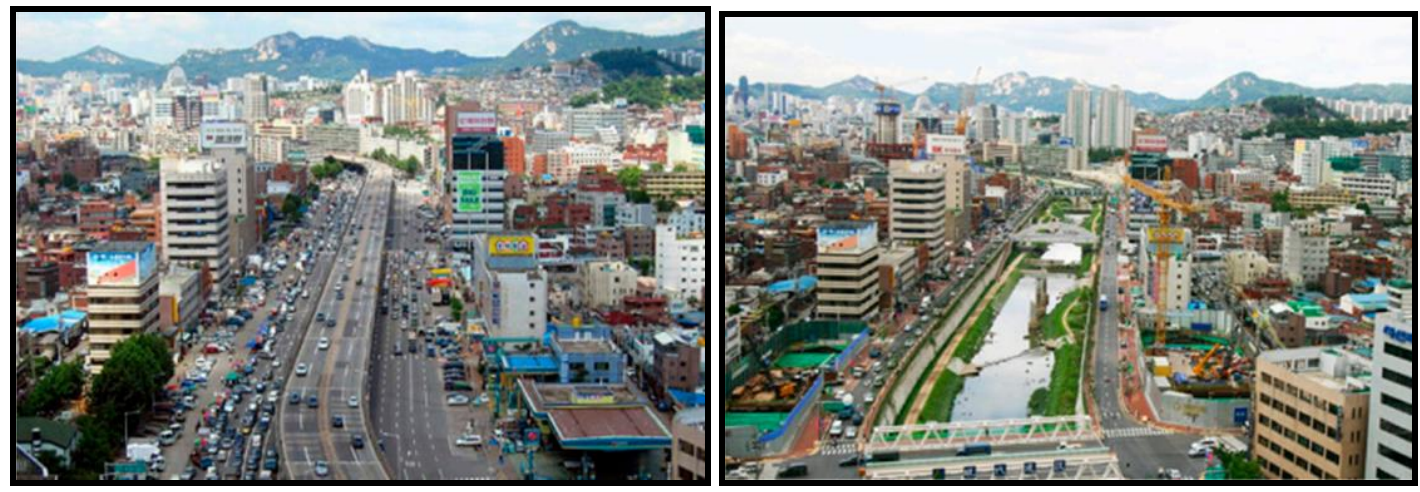

Şekil 1: Cheonggyecheon Nehir Restorasyonu Projesi Öncesi ve Sonrası (Ryu and Kwon, 2016, s. 4)

Bir diğer nehir restorasyon projesi ise 2004 y1lında Madrid'de gerçekleştirilen Rio Park Projesi'dir. 1970'lerde Avrupa'nın en büyük gelişmiş şehirlerinden biri olan Madrid'de şehri çevreleyen, nehir kıyılarını tahrip eden çok şeritli bir otoyol inşa edilmiştir. 2004 yılında hükümetin aldığı karar ile otoyol yeraltına alınarak nehir ve çevresi yeşil bölgeler ve bahçeler olarak kente geri kazandırılmıştır (Şekil 2).
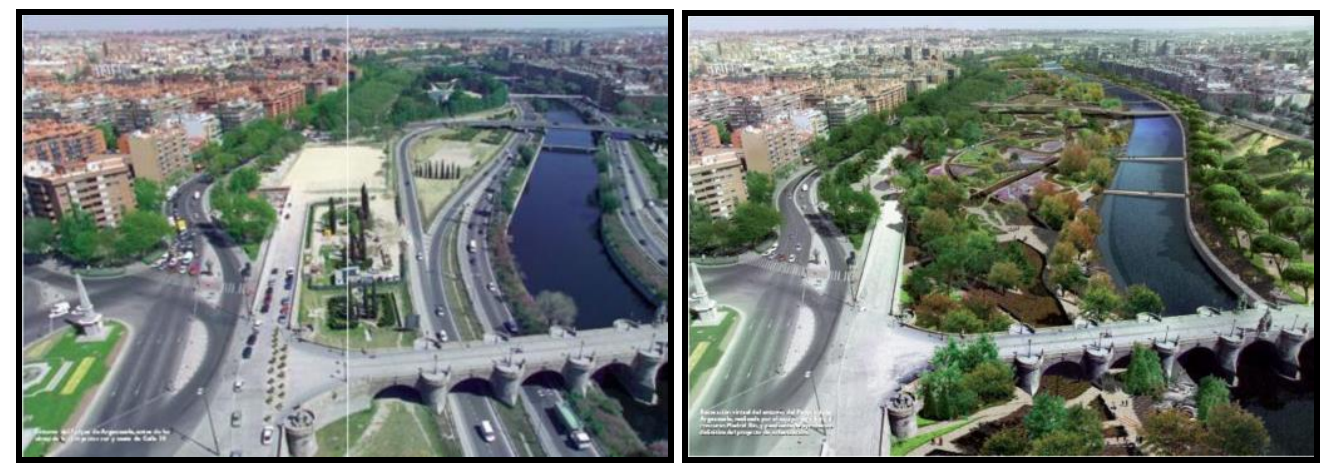

Şekil 2: Madrid Rio Park Nehir Restorasyonu Projesi Öncesi ve Sonrası (Best Practice: Large-Scale Green Space Reclamation Plan, 2012, s. 3) 
Madrid Rio Park Projesi ile yeni yeşil alan, parklar, oyun alanları ve eğlence alanları için alan yeni bir kentsel park alanına dönüştürülüp, mevcut parklarla bütünleştirmiş ve toplam 2.961 hektarlık bir ekolojik koridor oluşturulmuştur (Best Practice: Large-Scale Green Space Reclamation Plan, 2012, s. 1). Proje sonunda, yol yenileme planı ve yönetimin entegrasyonu yolu modern ve güvenli bir altyapıya dönüştürerek kazaları azaltılmış, trafik kazaları \% 50 oranında düşmüș, gürültü kirliliği azalmış, trafik sıkışıklığının azalması ve yer altına alınan otoyol tüneline monte edilen filtrelerle sera gazı emisyonların azalma gözlenmiştir (Best Practice: Large-Scale Green Space Reclamation Plan, 2012, s. 3-4).

Ülkemizde ise kentsel yeşil altyapının bütünsel olarak planlanmasında ulusal mevzuatımızdaki kanun ve yönetmeliklerde bir takım eksiklikler vardır. "Son on yılda mekânsal planlama sistemini belirli hedefler çerçevesinde oluşturmak için yapılan en kapsamlı çalışma 2009 yılında düzenlenen Kentleşme Şurası'dır. Şuranın hedefi, kentsel gelişme dinamiklerini sürdürülebilirlik ilkesi çerçevesinde değerlendirmek ve mekânsal planlama alanında bütüncül bir bakış açısı kazandırmak şeklinde tanımlanmıştır" (Gülçin, 2018, s. 61). Hazırlanan şura raporlarından yola çıkılarak "Türkiye'de kentsel yerleşmelerin mekânsal yaşam kalitesinin artırılmasına, ekonomik ve toplumsal yapının güçlenmesine, mekânsal planlama sisteminin yeniden yapılandırılmasına olan ihtiyacın giderek artmasından dolayı "Kentsel Gelişme Stratejisi ve Eylem Planı" hazırlanması öngörülmüştür" (Güler ve Turan, 2013, s. 254). KENTGES Eylem Planı'nın temel amacı, "yerleşmelerimizin yaşanabilirlik düzeyinin, mekân ve yaşam kalitesinin yükseltilmesi ile ekonomik, sosyal ve kültürel yapılarının güçlendirilmesine yönelik yol haritasının oluşturulmasıdır" (KENTGES Eylem Planı, 2010, s. 3). Bu kapsamda KENTGES Eylem Planı'nın stratejilerinden birisi de; "Yerleşmelerde açık ve yeşil alanların mekânsal planlar kapsamında sistem bütünlügü içinde planlanması sağlanacaktır" (KENTGES Eylem Planı, 2010, s. 29). Ülkemizde ulusal düzeyde yapılan çalışmalar ve stratejiler dâhilinde yeşil altyapı bütünlügünün sağlanması için düzenlemeler devam etmektedir. Fakat yeşil altyapının bileşenlerinden biri olan yeşil-mavi koridorların, kentsel yapılaşmanın altında kalan akarsu sistemlerinin restorasyonu ile geri kazanımının henüz somut örneklerine rastlanmamaktadır.

Kentlerde yapay su elemanları yerine doğal su kaynakları değerlendirilmesi ekosistem sağlı̆̆ açısından da oldukça önemlidir. Ülkemizde kent içerisinde kalmış su kaynakları ne yazık ki etkin bir şekilde kullanılamamaktadır. Geçmiş yıllardan bugüne kentlerde hızla artan kentsel nüfus çarpık yapılaşma ve gecekondulaşmayı beraberinde getirmiştir. Kent merkezinde kalan dere yatakları hızla kirletilmiş etkin ve sürdürülebilir planlamaya yaklaşımı ile korunamamıştır.

Cumhuriyetin ilan edilmesinden günümüze kadar olan süreçte, Ankara; doğal ve tarihsel değerlerinin büyük bir kısmını kaybetmiştir. Aslında bu durum Cumhuriyetin ilk yıllarında köylerden kente göç ile başlamış ve dereler etrafinda hızla gecekondular yayılmıştır. Artan altyapı ihtiyacı karşılanamayınca evsel ve sanayi atıkları derelere verilmeye başlanmış ve dereler açık kanalizasyon hatları haline gelmiştir. Bu duruma bir çözüm üretilememiş ve dereler beton menfezler içine alınmıştır. Bu durum günümüzde de değiştirilememiştir. Hala birçok derenin üzeri kapalı ya da kanala alınmış olup su izini yer üstünden takip etmek mümkün değildir. Bugün trafik ve altyapı ihtiyacı bu derelere gömülü durumdadır, dereler trafiği taşıyan kanallara dönüştürülmüştür. $\mathrm{Bu}$ çalışmanın asıl amacı ulaşım sistemleri için Ankara'nın doğal değeri olan derelerinin yok edilişini ortaya koymak ve Ankara'nın üzeri kapatılan ilk deresi olan Bent Deresi'nin geçmişteki ve bugünkü kullanımlarını çevreye olan etkileriyle karşılaştırmaktır.

$\mathrm{Bu}$ çalışmanın ilk bölümünde ulaşım hizmetleri için üzeri kapatılan/kanala alınan derelerin günümüzde kent yaşamına ve ulaşım sistemlerine verdiği zararlar, aynı şekilde ulaşım hizmetleri için de derelerin işgal edilmesi ortaya konmaktadır. Literatürde yapılan çalışmalardan, gazete haberlerinden, eski fotoğraflardan ve Asfaltın Altında Dereler Var Belgesi'nden de (Semiz, 2019) yararlanılarak derelerin varlığı ve ulaşım sistemleriyle etkileşimi tartışılmaktadır.

İkinci bölümde ise ilk bölümde açıklanan derelerden birisi olan, Bentderesi'nin kuzeybatıda Çubuk Çayı'na, doğuda Hatip Çayı'na döküldüğü noktalar sınır olmak üzere Ankara Kalesi’nin hemen kuzeyinde bulunan Bentderesi Caddesi ve çevresi araştırılmaktadır. Üzeri kapatılan ilk Ankara deresi olması sebebiyle Bent Deresi araştırma alanı olarak seçilmiştir. Bu çalışmada arşiv kaynaklarına başvurulmuştur. Ankara'nın şehir planları ve haritaları, eski fotoğraf arşivleri, gazete haberleri ve hava fotoğrafları kullanılarak derenin bugünkü durumu ortaya konmuştur. 


\section{Ankara'nın Akarsu Sistemi}

Ankara kenti, üç akarsu havzası içerisinde yer almaktadır. Bu havzalar; Sakarya, Kızılırmak ve Konya kapalı havzalarıdır. Ankara Ovası batıdan doğuya uzanan, kuzey-güney ve doğu kenarlarında kapalı olan paralel bir dağ sırtı ile tanımlanmaktadır. Kente doğru çıkıntı yapan bu dağlar arasında vadiler boyunca akan birçok akarsu ve dere vardır. Bu akarsu ve derelerden en önemlileri Şekil 3'te görüldüğü üzere, kentin kuzeydoğusundan gelen Çubuk Çayı, doğusundan gelen Hatip Çayı ve güneydoğusundan gelen İncesu Deresidir. Bu üç dere birleşerek Ankara Çayı'nı oluşturmaktadır. Birleşim güzergâhlarının çoğunda derelerdeki su izine bugün kent yüzeyinde rastlanılamamaktadır.

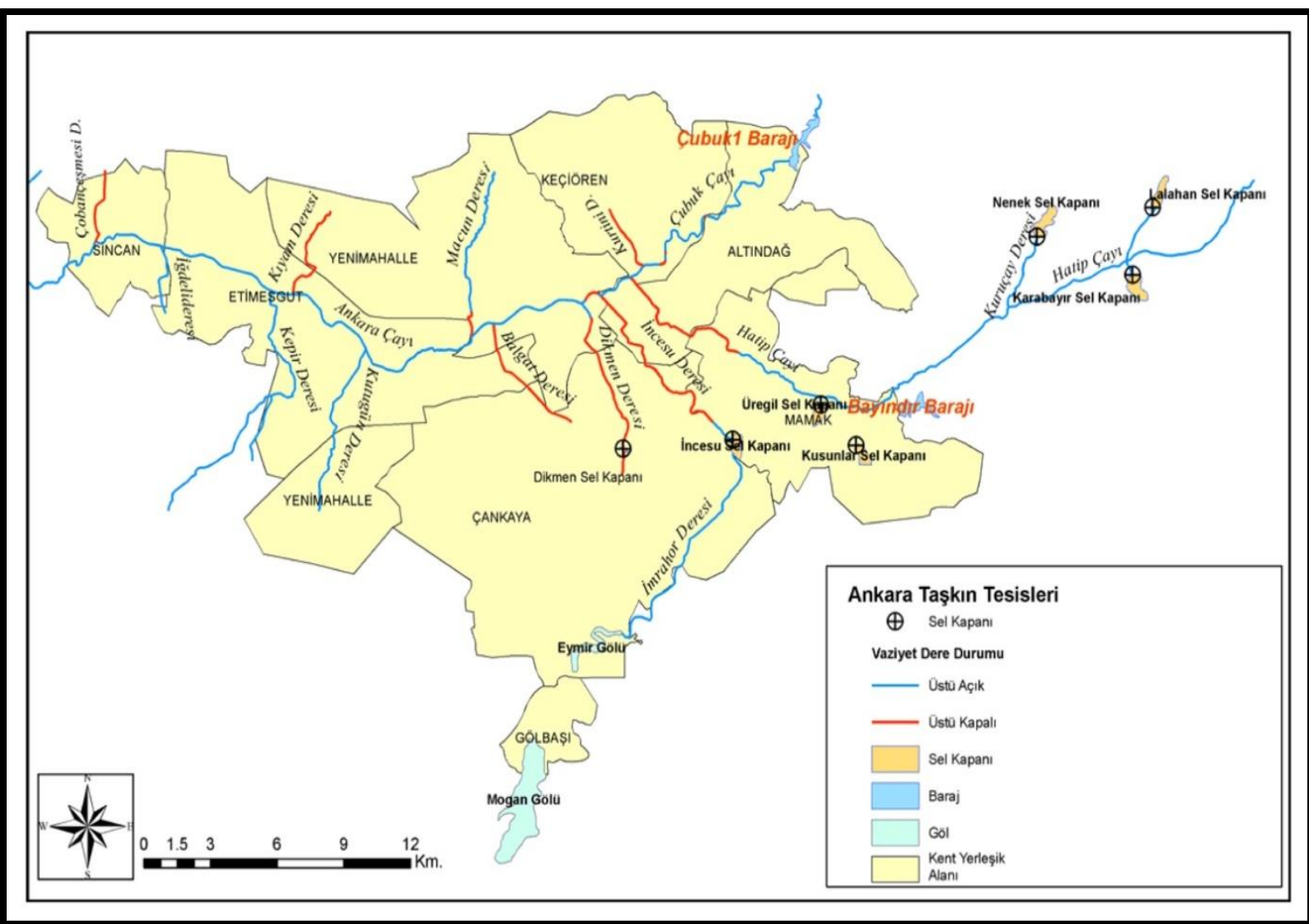

Şekil 3: Ankara Çayı ve Çevresi Taşkın Tesisleri (Pekin, 2007, s. 112)

Çevre ve inşaat yüksek mühendisi Hasan Akyar'ın da belirttiği gibi (URL, 1), Ankara'da günlük yolculuklar sırasında Kutlugün Deresi, Cevizlidere, Hoşdere, Bülbül Deresi, Dikmen Deresi, Söğütözü Deresi, Kirazlıdere ve Bent Deresi gibi farkında olmadan birçok derenin üzerinden geçilmektedir (Şekil 4).

\section{Ankara'nın Kayıp Dereleri}

“Ankara'nın başkent olarak ilan edilmesinden önce ve genç Türkiye Cumhuriyeti'nin ilk dönemlerinde kentin dereleri ve çayları halkın rekreasyonu için önemli yerlerdi ve ayrıca tatlı su arzı ve hatta balıkçılık için de kullanılıyordu. Ancak, bu çay ve derelerin çoğu, 1923'te Ankara'nın Türkiye'nin başkenti olması nedeniyle uygulanan kentsel ve su politikalarının bir sonucu olarak, bugün şehir manzarası içinde görünmez ya da çok az görünür durumdadır” (Kaymaz, 2019, s. 2). Örneğin Şekil 5 'te Sıhhiye Atatürk Bulvarı üzerinde görülen İncesu Deresi'nin izine bugün Atatürk Bulvarı'nda hiç rastlanılmamaktadır. 


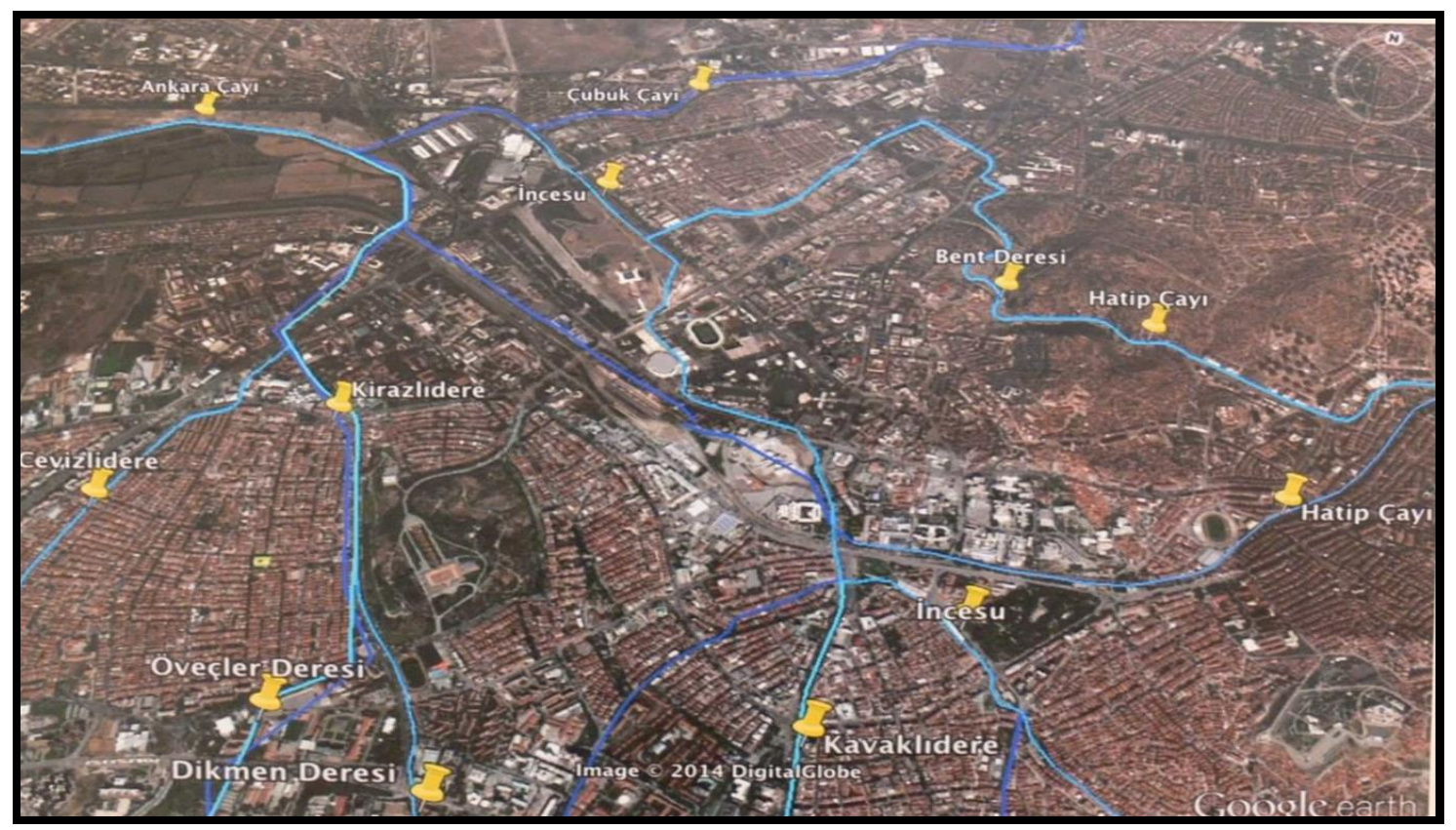

Şekil 4: Ankara'nın Kaybolan Dereleri (URL, 1)

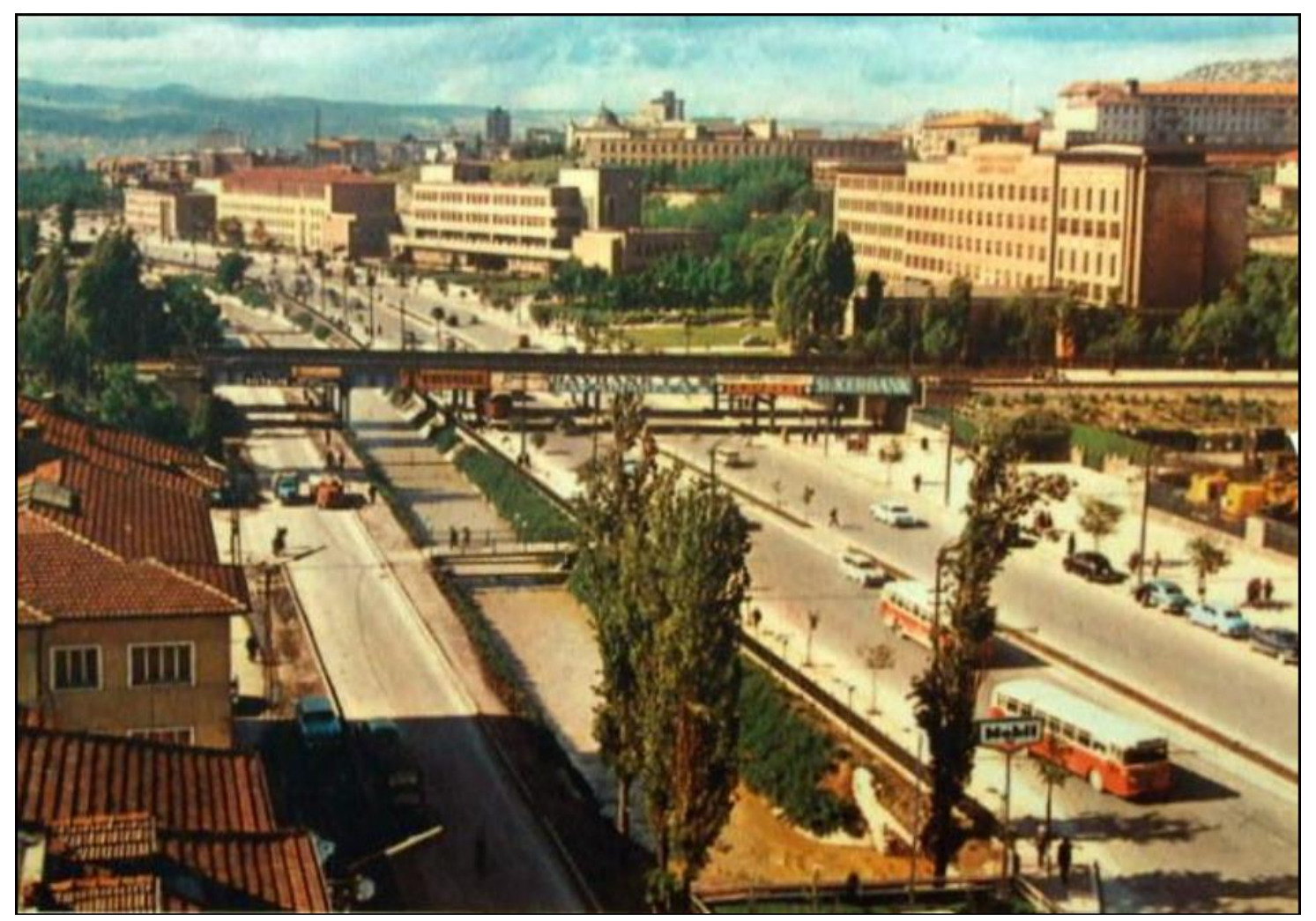

Şekil 5: 1960/1970 Sihhiye Kartpostal1-İncesu Deresi (URL, 2)

\section{Ankara'da Meydana Gelen Su Taşkınları}

Yoğun kentsel yapılaşma ile bugün derelerin, kentin hangi güzergâhında ilerlediklerini tespit etmek zordur. Fakat doğal yatağı bozulan derelerin bazılarının isimleri bugün cadde ve sokaklara verilmiştir (Şekil 6). Aynı şekilde aşırı yağışlarda meydana gelen sel felaketleri de bu cadde ve sokaklarda ortaya çıkmaktadır. Çünkü doğal dere yatakları beton menfezler içine alınmıştır ve su, bugün inşa edilen yolları dere yatağı olarak kullanmaktadır. 

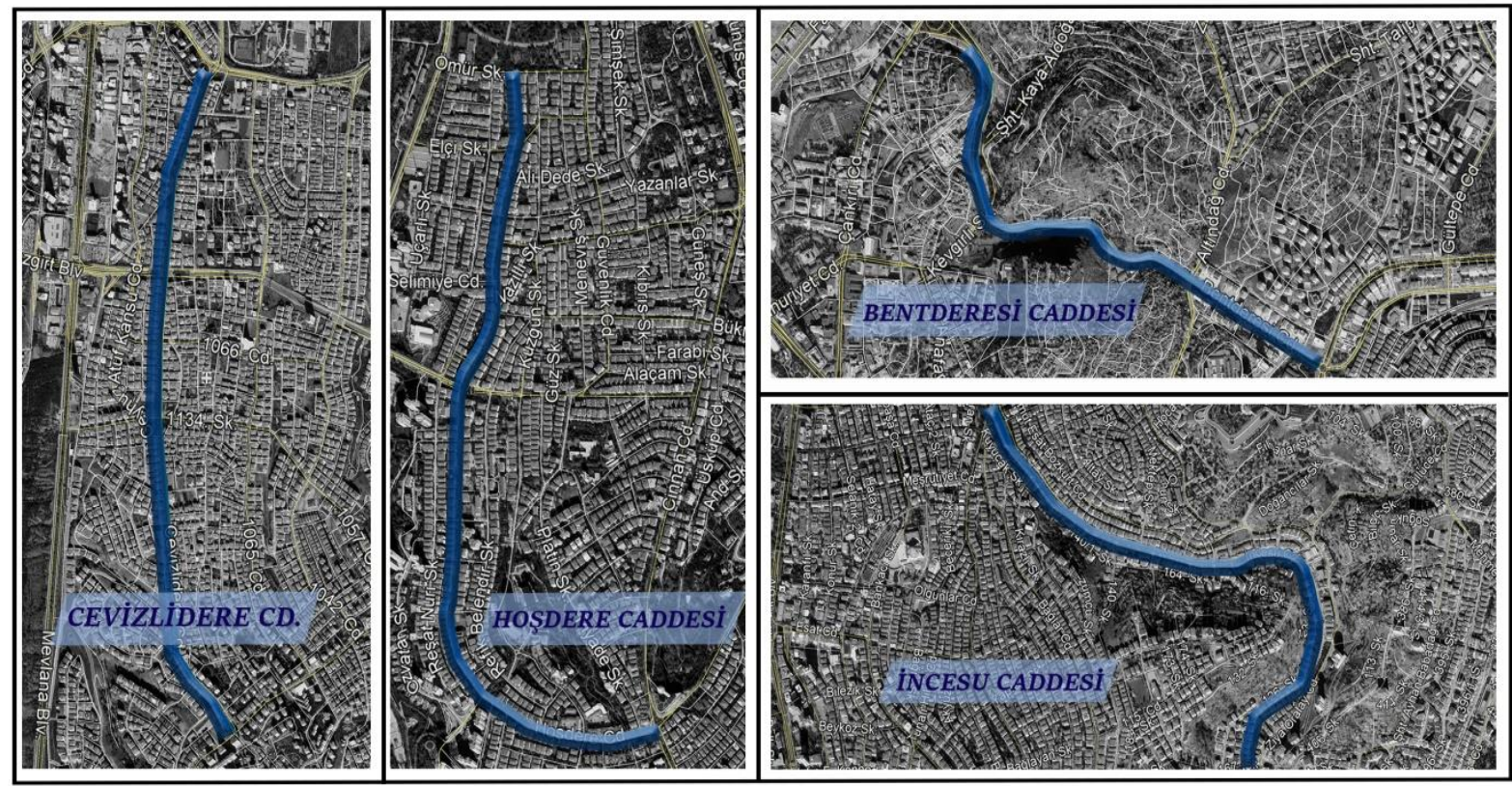

Şekil 6: Dere yataklarında bulunan yollara verilen cadde isimleri (Google Earth, 2019)

Çayyolu'nda bulunan Gordion AVM ve çevresini hemen yakınında bulunan Kutlugün Deresi'nden dolayı aşırı yağışlarda su basmaktadır. Benzer şekilde 70. Gün Altgeçidini de altından geçen Cevizlidere'den dolayı aşırı yağışlarda su basmaktadır (Şekil 8).
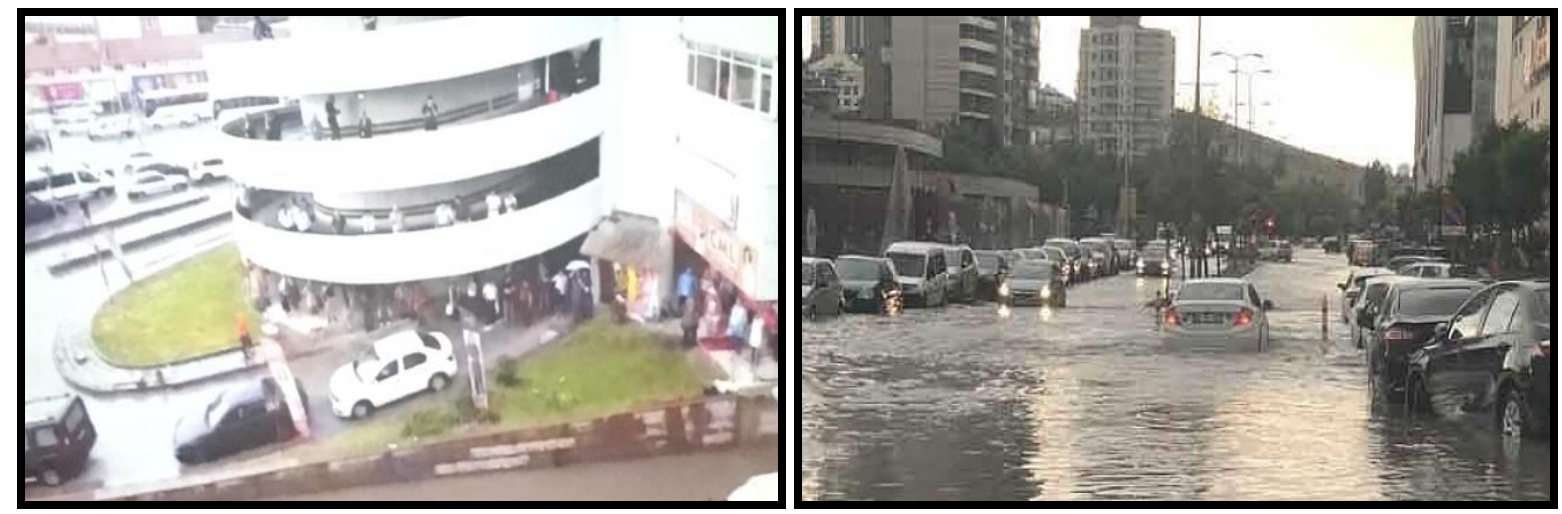

Şekil 7: Çayyolu Gordion AVM ve çevresi su baskını (Semiz, 2019) (URL, 3)
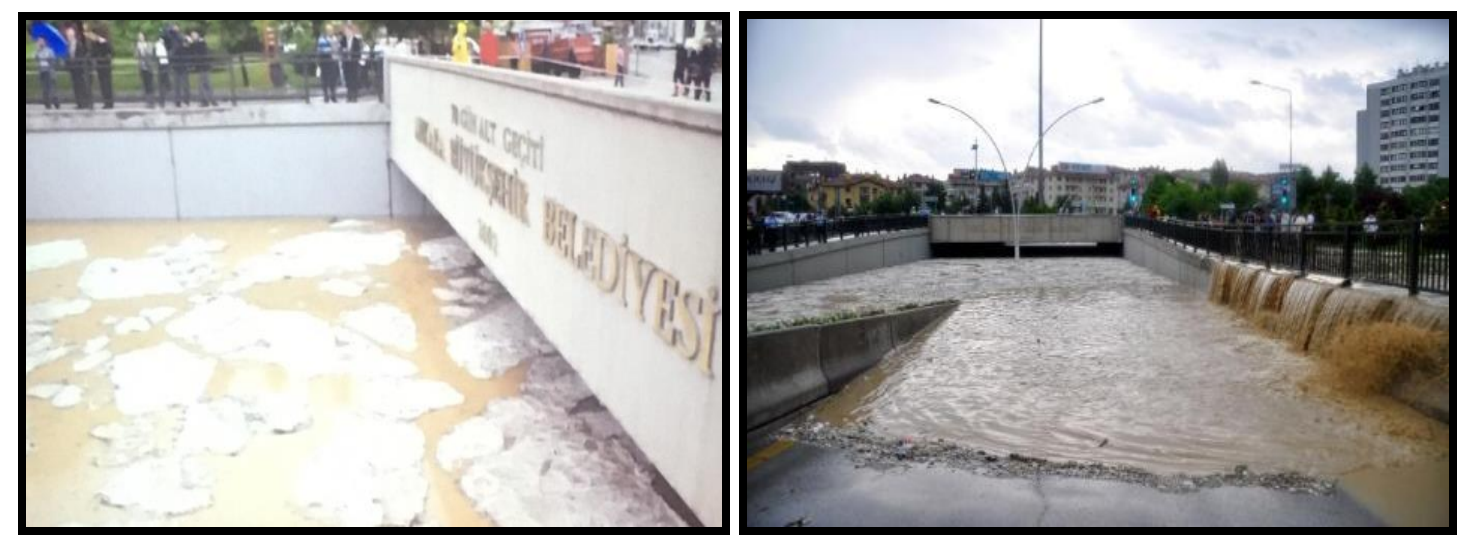

Şekil 8: 70. Gün Altgeçidi su baskını (Semiz, 2019) (URL, 4) 
Bir diğer sel felaketi ise 2018 Mayıs ayında Eskişehir Yolu ve Atatürk Hastanesi'nde meydana gelmiştir (Şekil 9). Çünkü o civarda da Eskişehir Yolu'nu kesen Ahmet Hamdi Akseki Camii yanından Beytepe Deresi akmaktadır. 2012 yılında ise İnönü Bulvarı'nda Hava Kuvvetleri Komutanlığı önündeki kaldırımda yürüyen bir vatandaş meydana gelen göçük sonrası kanalizasyon hattına düşüp metrelerce sürüklenmiş ve hayatını kaybetmiştir (Şekil 10). Yine o bölgede yer altına alınan Dikmen Deresi bulunmaktadır.
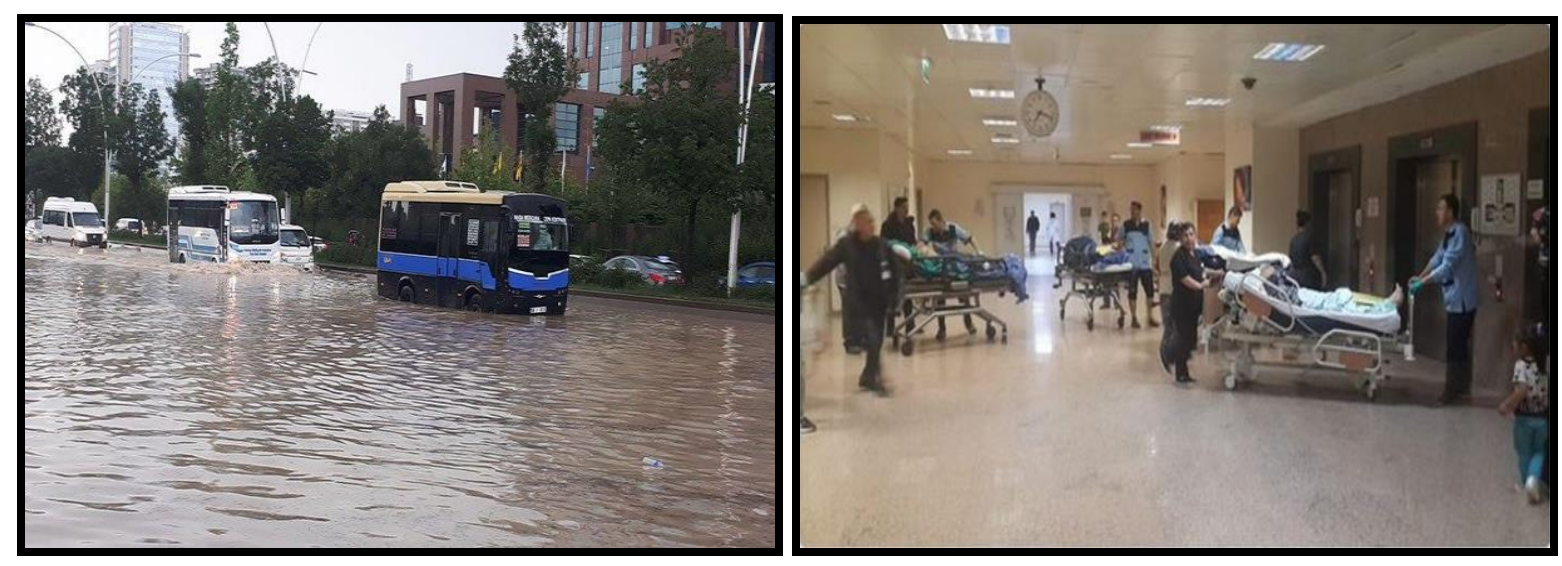

Şekil 9: Ankara Eskişehir Yolu ve Atatürk Hastanesi Su Baskını (URL, 5)
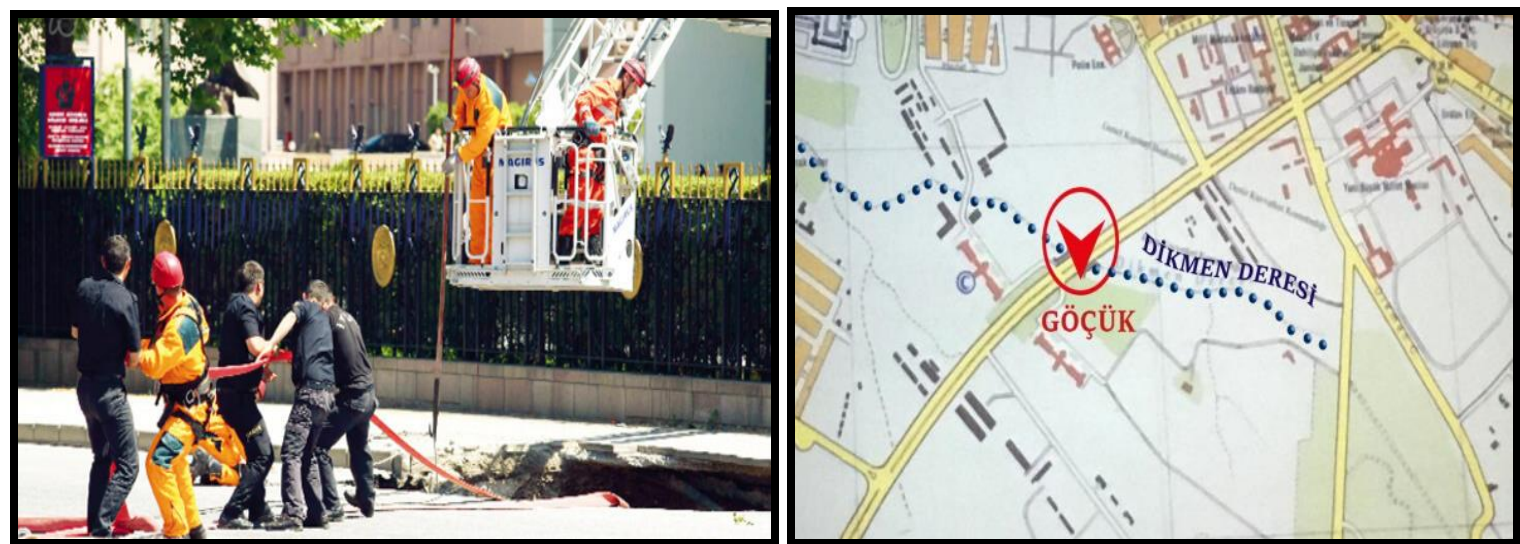

Şekil 10: Ankara Hava Kuvvetleri Komutanlığı Önünde Gerçekleşen Kaldırım Göçük Olayı (URL, 6) (Semiz, 2019)

Geçmişten bugüne Ankara'da yaşanan sel felaketlerinin aslında bir doğa olayı olmadığı açık bir şekilde görülmektedir. Geçmişte doğal dere yataklarının evsel ve sanayi atıkları ile kirletilmesi sonucu derelerin bir kısmının kapatılıp kanalizasyon hatları haline dönüştürülmesi bir kısmının beton menfezler içinde yer altından akması bugün ulaşım altyapısı ve üstyapısını tehdit etmektedir. Beton menfezler içinde akan derelerin ne durumda olduğunu tahmin etmek imkânsızdır. Bugün Ankara genelinde yollarda, altgeçitlerde, katlı kavşaklarda, bazı kamu kuruluşlarında, metro istasyonlarında meydana gelen seller tesadüfi değildir. Geçmişte zaten bu alanların dere yatağı olması sebebiyle aşırı yağışlar sonucunda seller meydana gelmekteydi. Geçmişte ve bugün alınan yanlış ulaşım kararları mal ve can kayıplarına sebep olmaktadır. Ulaşım hizmetlerini iyileştirmek için yapılan tüm yatırım maliyetleri aslında yanlış yerlerde ve eksik şekilde devam etmektedir. Hepsinin ötesinde dereler, iklim değişikliği ve artan küresel ısınmaya çözüm olabilecek birer doğal kaynak iken kirletilmeye ve yok sayllmaya devam edilmektedir. 


\section{Bentderesi’nin Mekânsal Değişimi}

Hatip Çayı, Ankara Kalesi eteklerinden geçerken üzerinde kurulmuş bulunan Roma Dönemi Su Bendi'nden dolayı "Bend Deresi” adını alır (Tunçer, 2013). Ankara'nın ilk haritası, Prusyalı H. Von Moltke'nin yanında gelen Kraliyet subaylarından, Kurmay Binbaşı Baron Von Vincke tarafindan 1839 yılında çizilmiştir (Günel ve Kılc1, 2015, s. 86). Von Vincke tarafindan çizilen 1839 Ankara Haritasında İncesu ve Bent Deresi ile Hatip ve Çubuk Çayı gösterilmiştir (Şekil 11). "Mustafa Kemal Paşa'nın önderliğinde Anadolu'da başlayan Kurtuluş Savaşı sürerken, İstanbul'da Harbiye Nezareti Harita Dairesi'nde görevli 22 haritacı subay, 1/4000 ölçekli 1924 Ankara Şehir Planı Haritasını oluşturmuşlardır" (Günel ve Kılc1, 2015, s. 79). Bu haritada da Bentderesi ve üzerinde bulunan köprüler gösterilmiştir (Şekil 12). "Haritada şehrin kuzeydeki dış konturlarını, doğudan gelen ve coğrafyaya uyumlu olarak devam eden Hatip ve Çubuk Çayları, güneyde ise demiryolu çizmektedir. Hatip Çayı, Roma su bendi ve on bir adet ahşap ve taş köprüyü geçerek kuzeye doğru devam etmektedir. Kuzeyde Çubuk Çayı ile birleşip kıvrılarak güney batıya dönen Hatip Çayı güneyden gelen İncesu (Bülbülderesi) ile birleşerek Ankara Çayı'nı oluşturmaktadır'(Günel ve Kılcı, 2015, s. $81)$.

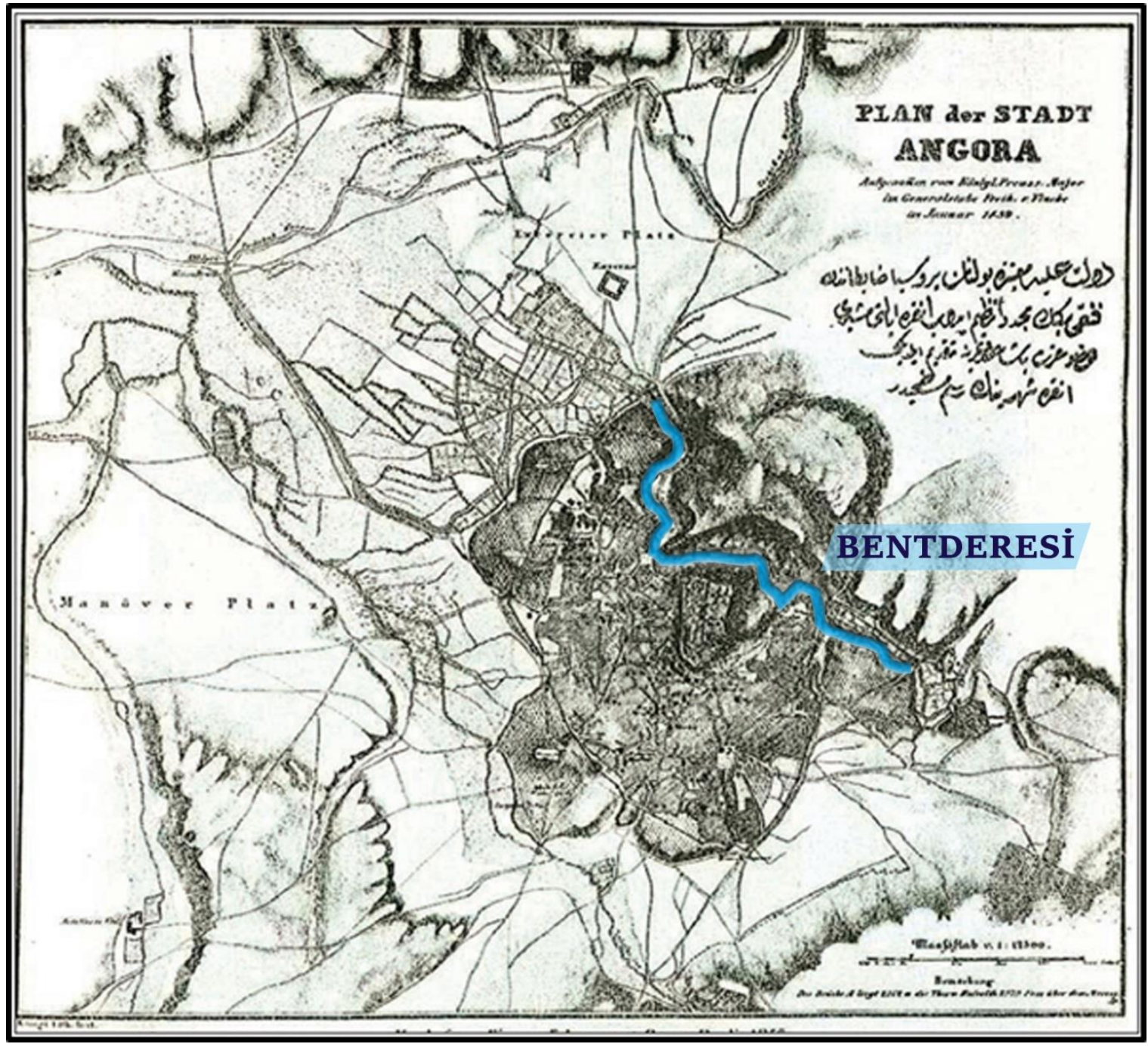

Şekil 11: Von Vincke'nin Ankara Haritası 1839. (Günel ve Kılc1, 2015, s.88) 


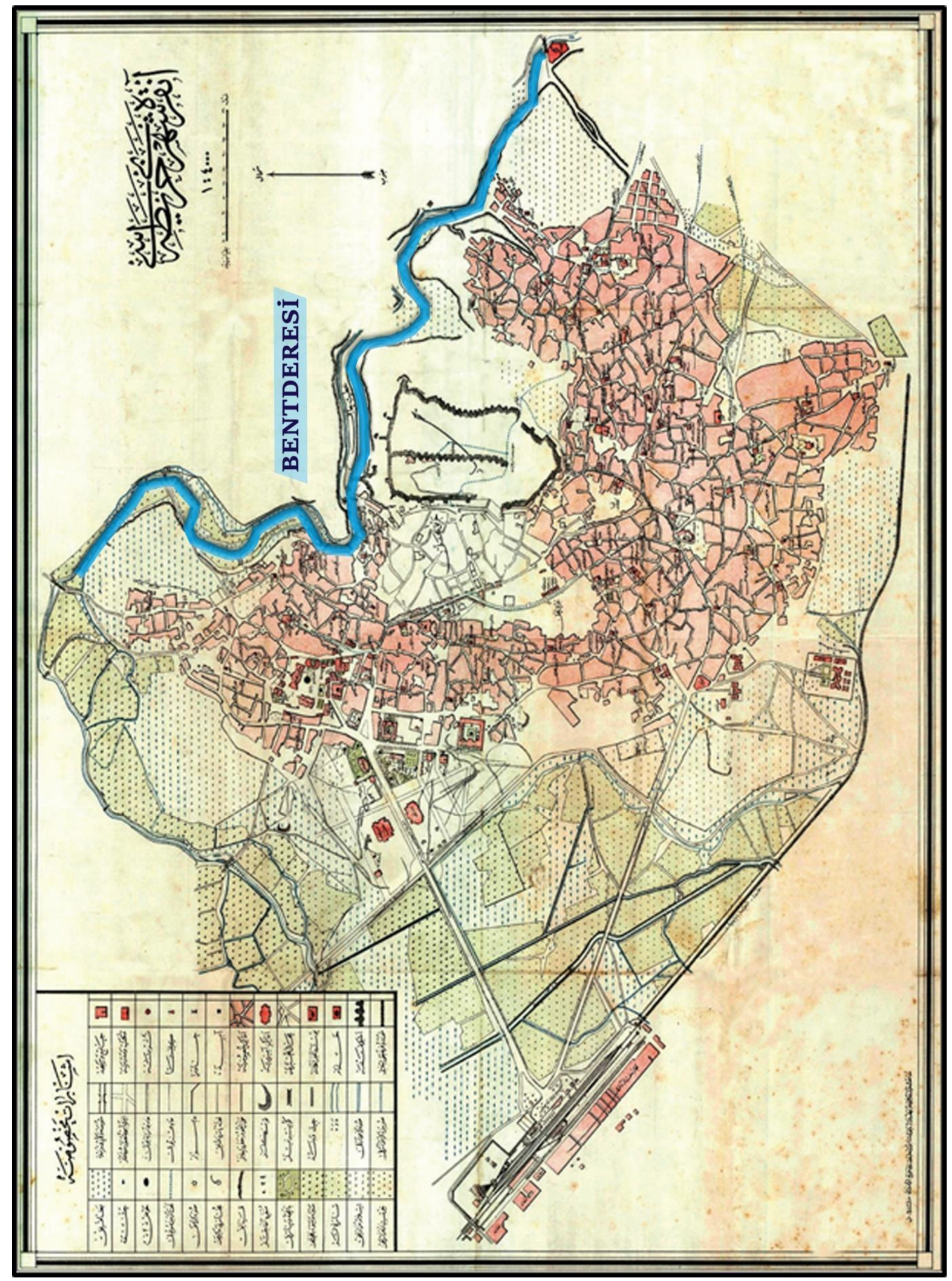

Şekil 12: Ankara 1924 Haritası (Günel ve Kılc1, 2015, s.80) 
Alman mimar ve şehir plancısı Profesör Hermann Jansen'in Ankara Şehri İmar Plan'ında da Bent Deresi ve çevresini korumayı hedeflemiş, Bent Deresi boyunca yeşil alan ve bir de havuz tasarlamıştır (Şekil 13 ve 14). O dönemde Bent Deresi korunmaya çalışılmıştır.

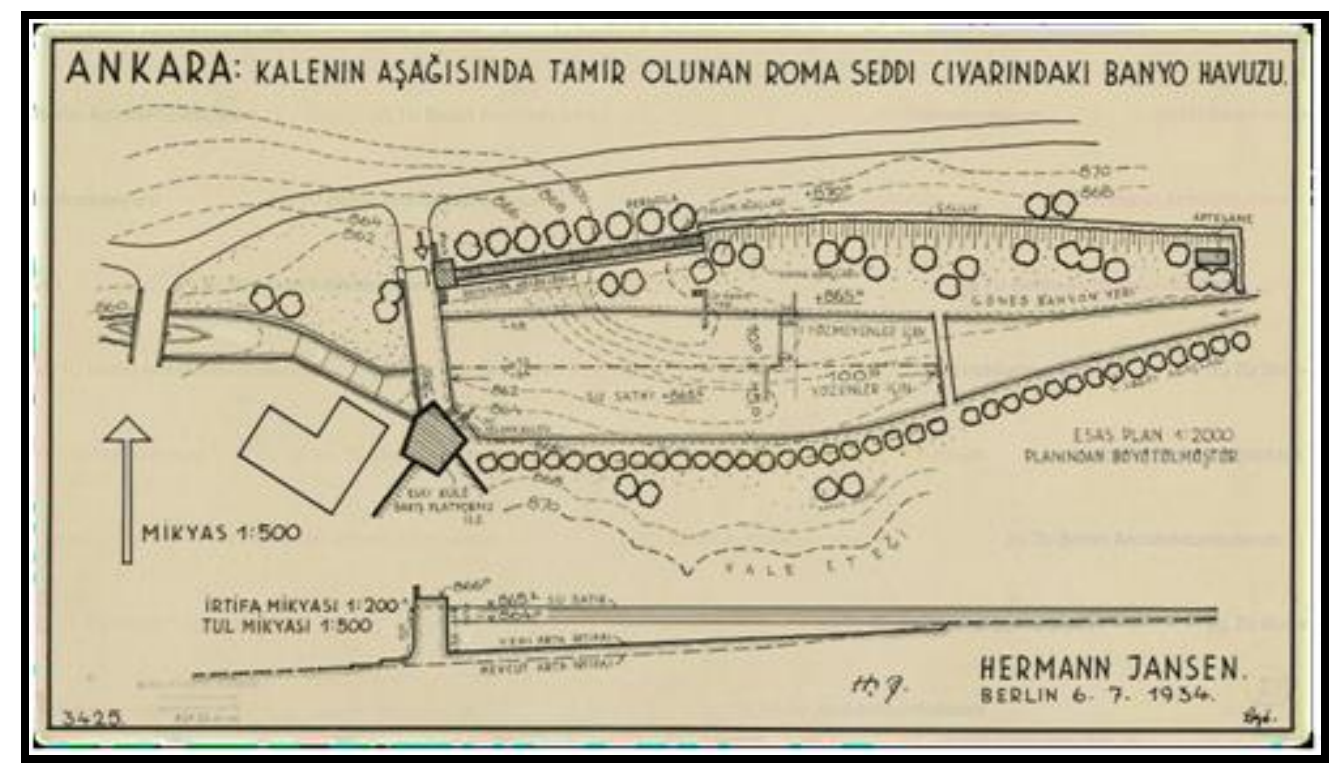

Şekil 13: Hermann Jansen'in Roma Seddi Civarındaki Banyo Havuzu Planı (URL, 7)

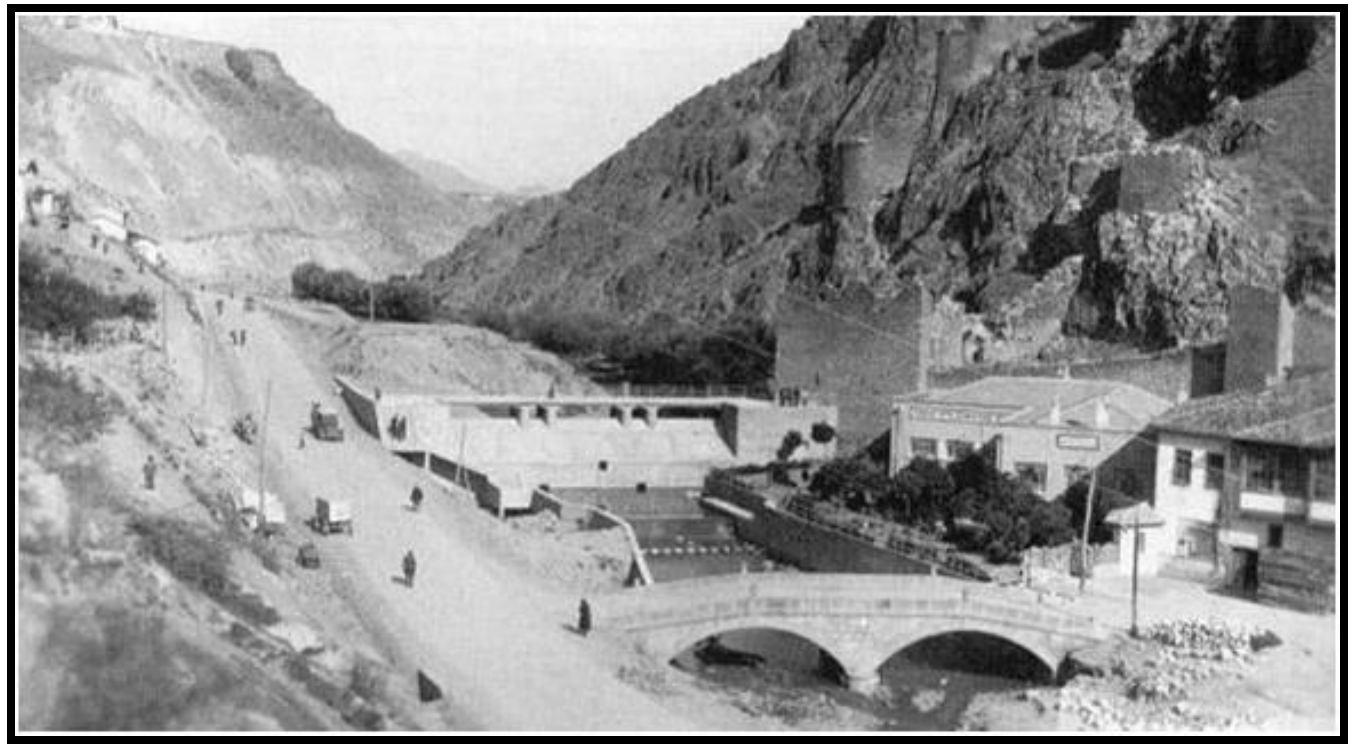

Şekil 14: 1930'larda Bent Deresi (URL, 7)

Fotoğraf arşivlerinde Bent Deresi üzerindeki köprüler, dere etrafina yerleşen kahvehaneler ve derede yüzen insanlar görülmektedir (Şekil 15). Bent deresi başlangıcında derenin akış hızı aniden arttı̆g için 1940'larda bir değirmen de kurulmuş ve tahıllar bu değirmende öğütülmüştür. Köyden kente artan yoğun göç sebebiyle birçok insan Bent Deresi etrafina yerleşmiş ve gecekondu yapmıştır. "1956 yılında belediye, Bent Deresi sakinlerine; dereyi 1slah edeceğini, kanal yapacağını, daracık yolu 50 metre genişliğinde bulvar yapacağını söyleyerek; bölgedeki kaçak gecekonduları istimlak edeceğini bildiren bir tebligat yollamıştır" (Kaynar, 2014, s. 218). Dere ıslahı ve istimlak çalışmaları devam ederken, 1957 yılında sel felaketi meydana gelmiştir. Belediyenin tebligatına uyan Bent Deresi sakinlerinin bir kısmı evlerini sel felaketinden önce boşaltmıştır. "Evlerini boşaltmayanlar ise, sel günü alçaktan uçan uçakların "sel geliyor, evlerinizi terk edin" uyarısını, evleri istimlak etmeye çalışan belediyenin bir oyunu olduğunu düşündükleri için dikkate almamışlardır. Sel felaketinden sonra Bent Deresi üzerindeki köprüler yıktırılmış ve dere DSİ tarafından menfez içine alınarak (Şekil 16) üzerinden 10 metre 
genişliğinde yol geçirilmiştir” (Kaynar, 2014, s. 218-220). Bu sel felaketinde 130 kişi hayatını kaybetmiştir. Cumhuriyetin ilan edilişi ve sel felaketinden sonra Bent Deresi ve çevresinin, gezi ve park alanı işlevi tamamen yok olmuştur. Bugün Bentderesi Caddesi altından akan Bentderesi kanalizasyon hattı görevi görmektedir (Şekil 17).

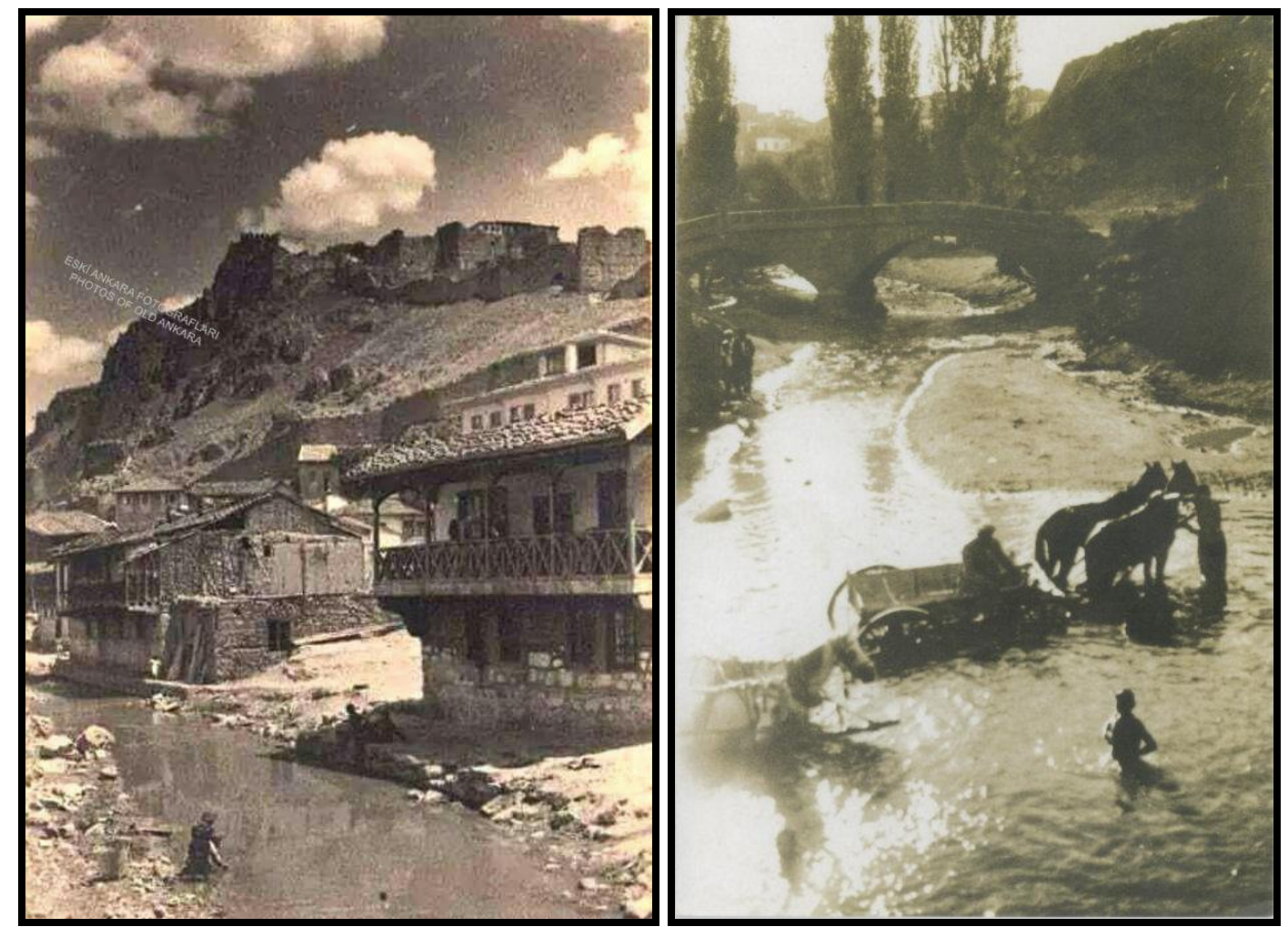

Şekil 15: Bent Deresinde yüzen insanlar (URL, 8) (URL, 9)

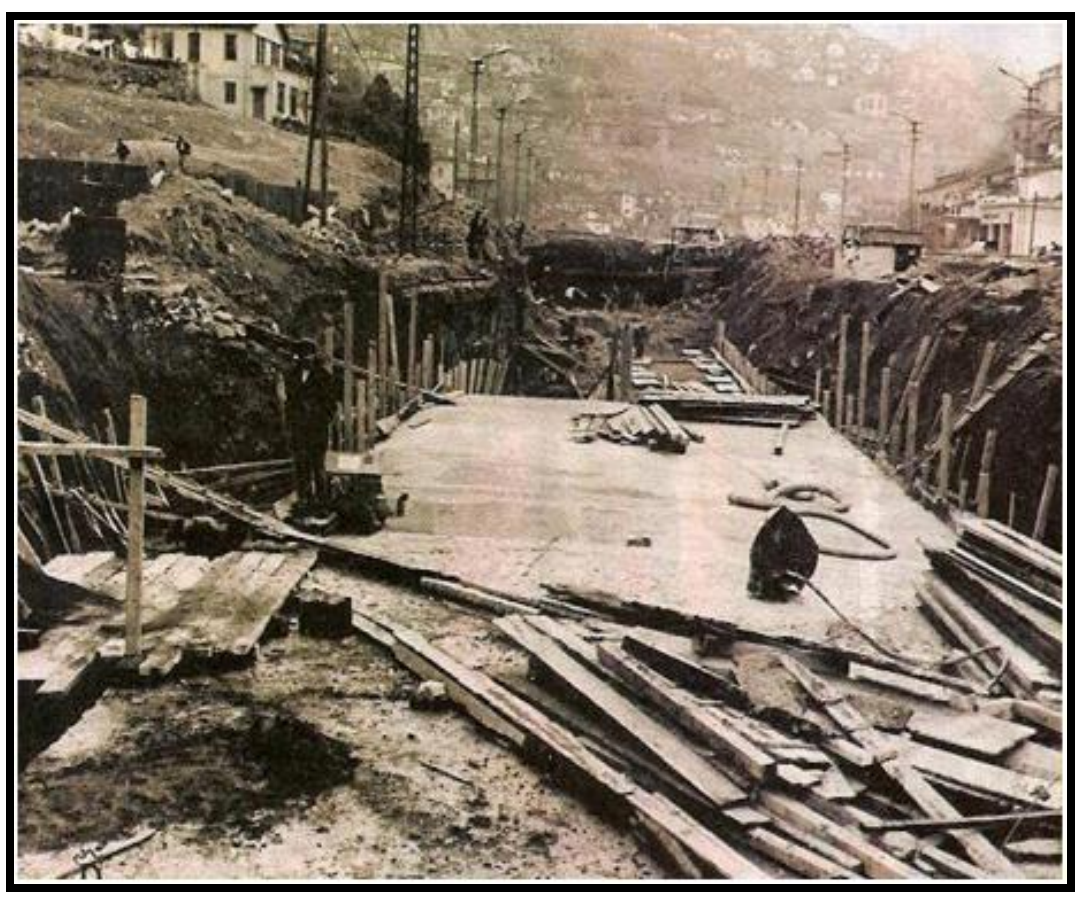

Şekil 16: Bent Deresi’nin üzeri kapat1lırken (URL, 7) 


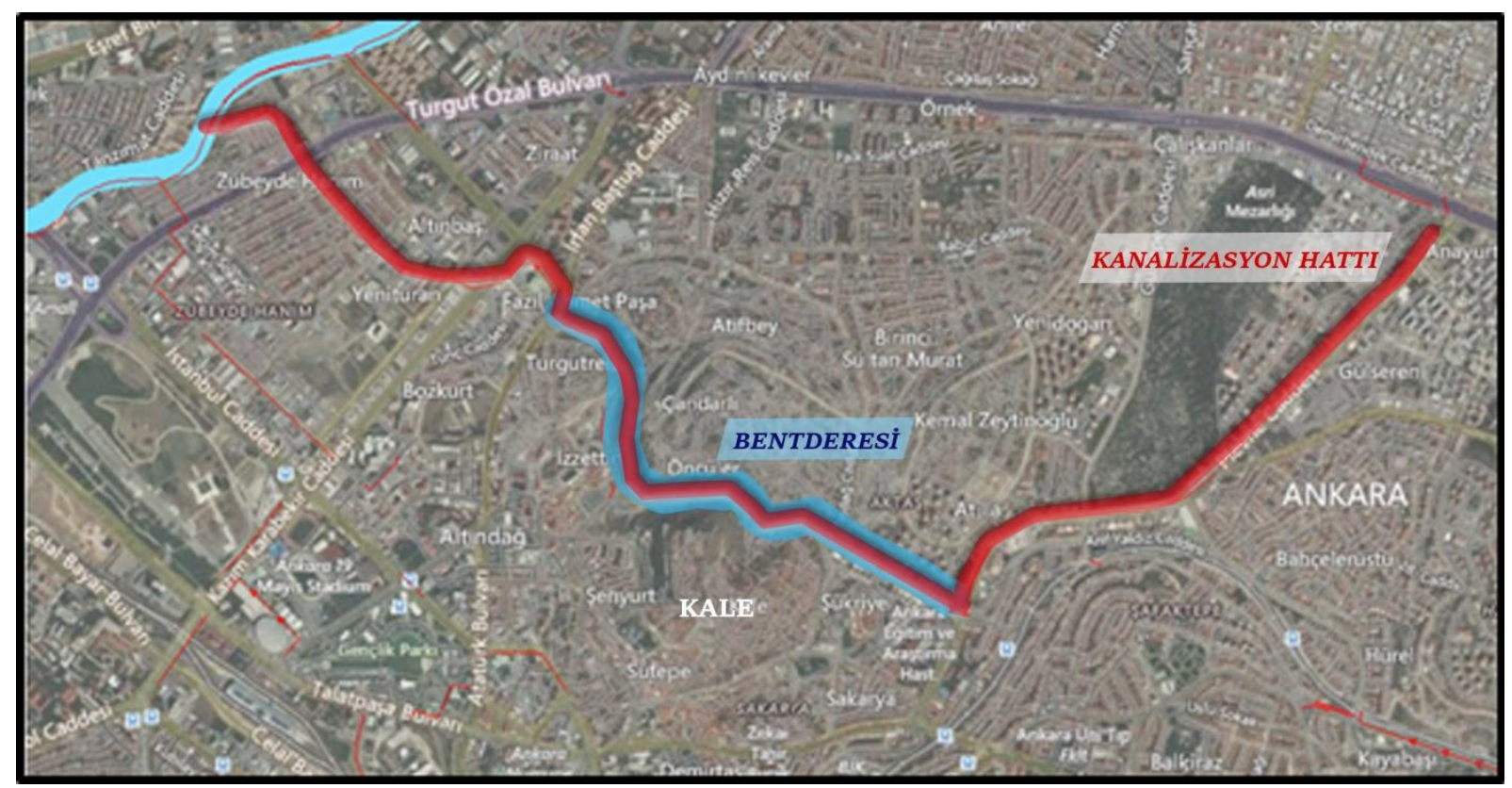

Şekil 17: Ankara 2038 Çevre Düzeni Planı'nda Gösterilen Kanalizasyon Hattı

Günümüzde beton menfezler içine alınan derenin üzerine inşa edilen Bentderesi Caddesi boyunca araç trafiği akmaktadır (Şekil 18). Dışkapı Kavşağı ile Aktaş Kavşağı arasında yer alan Bentderesi Caddesi yaklaşık 2,33 kilometre uzunluğunda ve 30 metre genişliğindedir. Trafik ve trafik altyapı ihtiyacı Bent Deresinin üzerine inşa edilmiş durumdadır.

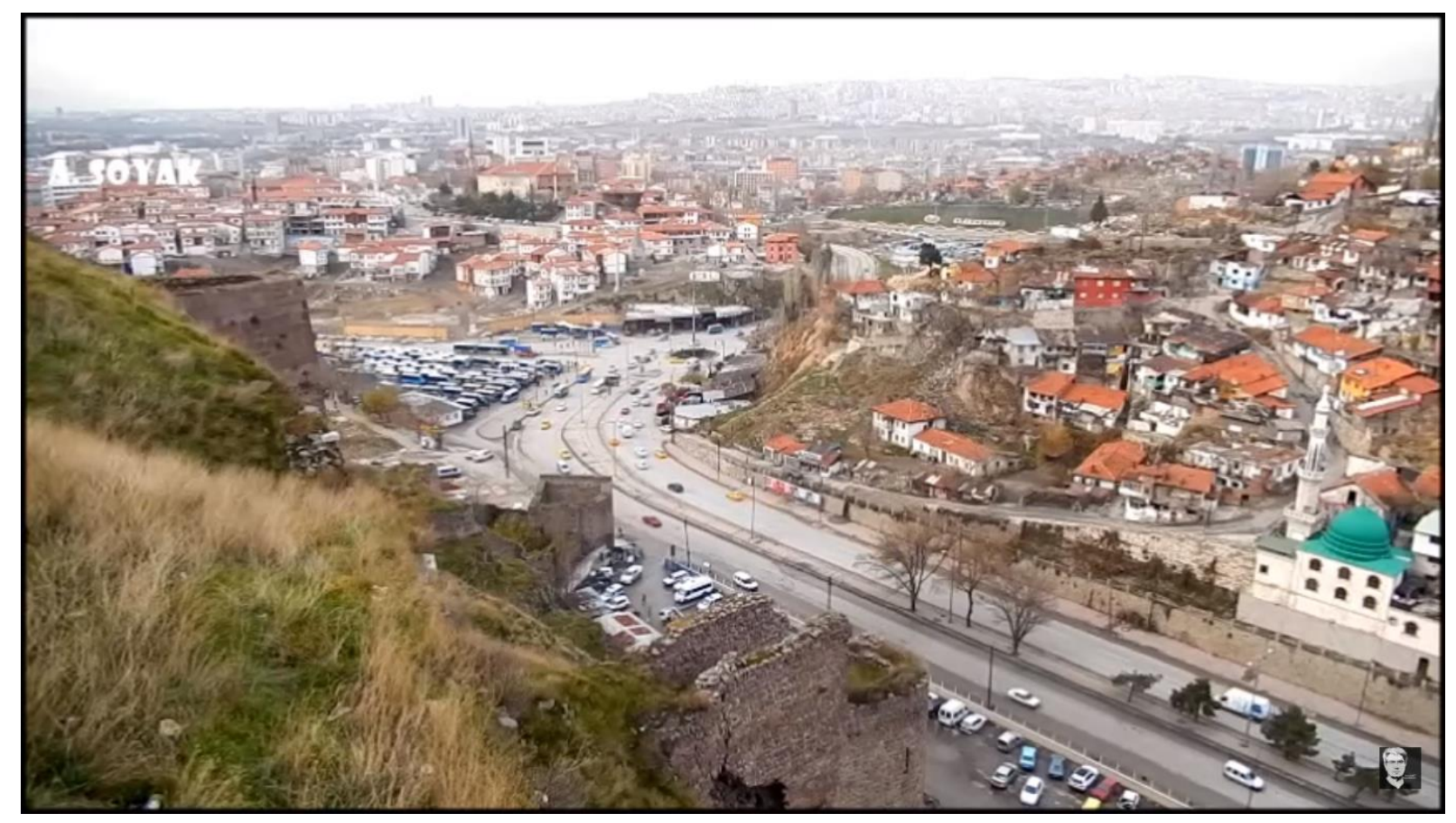

Şekil 18: 2014 Y1l Bentderesi Caddesi (URL, 10)

Şekil 19'daki Von Vincke'in 1839 Ankara Haritası ve 1924 Ankara Şehremaneti Haritası'nda Bent Deresi'nin ve çevresinin arazi kullanımına bakılacak olursa, dere etrafında henüz bir yapılaşma görülmemektedir. Dere doğal yatağında akmakta, çevresine ve üzerine herhangi bir müdahale bulunmamıştır. Bent Deresi'nin 1944 arazi kullanımında ise dere etrafında gecekondu alanları görülmektedir. Gecekondulardan kaynaklanan kanalizasyon atıkları ile dere kirletilmiş, 1957 yılında 
gerçekleşen sel felaketi sonrası beton menfez içine alınıp üzeri kapatılmıştır. Bugün Bentderesi Caddesi'nin altında dere kanalizasyon hattı olarak akmaya devam etmektedir. Caddeye cephe veren işlevler ticaret, turizm, konut alanları, sağlık ve eğitim tesis alanlarından oluşmaktadır. Çevresindeki kentsel işlevlere bağlantı sağlaması sebebiyle toplam 6 şeritten oluşan Bentderesi Caddesi boyunca yoğun araç trafiği akmaktadır. Geçmişte birçok sel felaketinin meydana geldiği bu dere, iki tepe arasında kalan aşırı yağışlarda yoğun trafik ile yağmur sularının da akmaya devam ettiği bir dere yatağıdır. Hem Bentderesi hem de çevresi ekolojik fayda değerini kaybetmiştir.

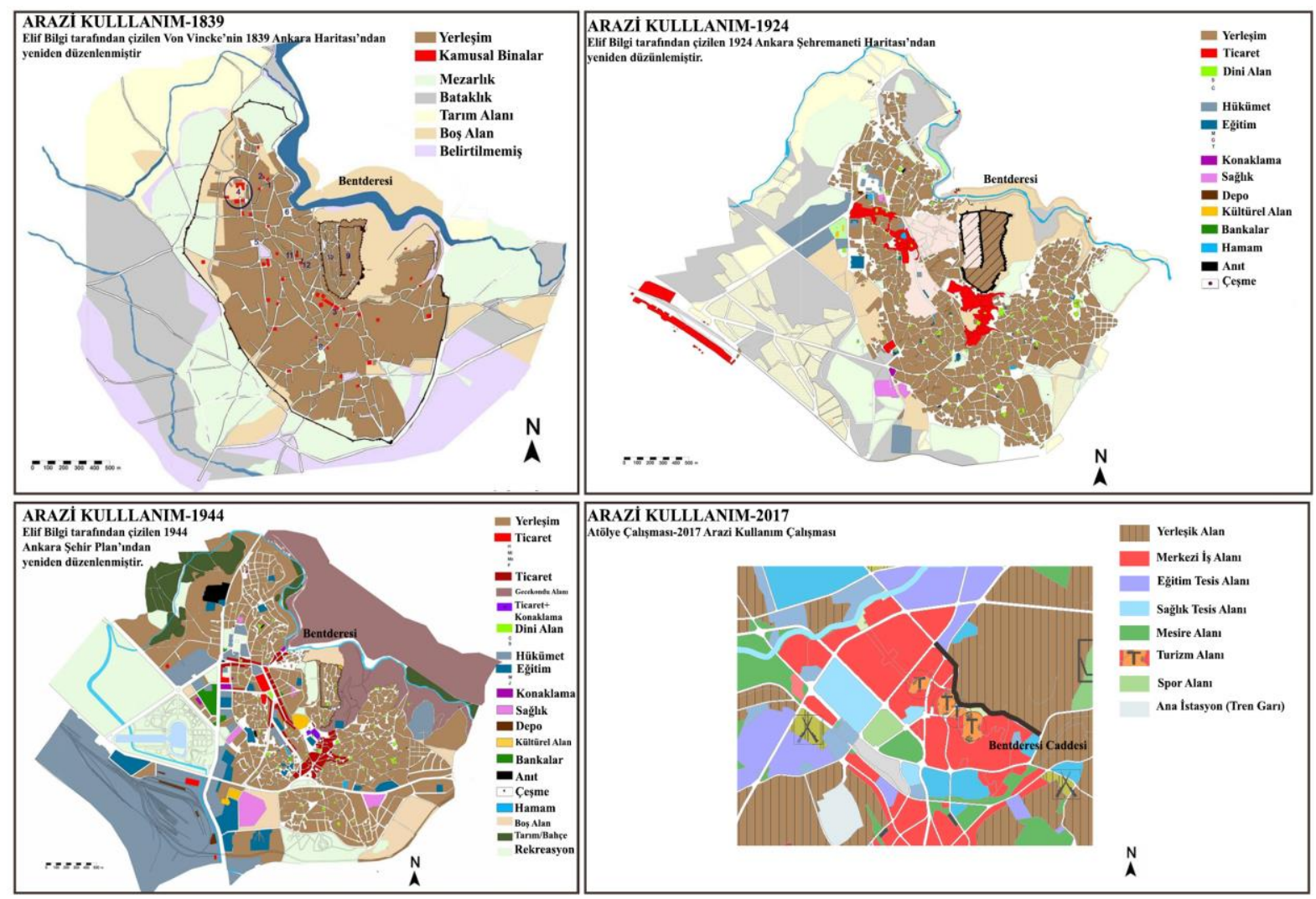

Şekil 19: Bentderesi ve Çevresinin Arazi Kullanımı

(Mıhçığlu Bilgi, 2010, s. 42, s. 69, s. 173) (Atölye Çalışması, 2017)

\section{SONUÇ}

Ankara kuruluşundan bu yana hızla artan nüfus sebebiyle kentleşme politikalarında yetersiz kalmıştır. Kentsel formu şekillendirme konusunda yapılan planlar yetersiz nüfus tahminleri sebebiyle gerçekleştirilememiştir. 1950'li yıllardan itibaren artan nüfus sebebiyle dere yataklarında ve vadilerde artan gecekondulaşma ile dereler kirletilmeye başlanmıştır. 1957 yılında Hatip Çayı'nın kolu olan Bent Deresi'nde gerçekleşen sel felaketi ile Ankara'da derelere ilk müdahale başlamıştır. Sel felaketinden sonra doğal ve tarihi değerini yitiren Bent Deresi ulaşım sistemlerinin altında bırakılmıştır. Bugün Ankaralılar hangi derenin hangi caddenin altından geçtiğinin farkında değildir. Derelerin üzerinden geçen cadde ve sokaklara verilen isimler ile altından hangi derenin geçtiği tahmin edilmeye çalışılmaktadır. Bunun en somut örneği olan Bentderesi Caddesi, Ankara'nın ilk yerleşim yeri yakınlarında yer alması sebebiyle daha somut olarak bilinmektedir. Hermann Jansen planlarında Bentderesi alanını korumaya çalışmışır. Fakat 1950'lerden bu yana doğal bir değer olan Bentderesi sürdürülebilir bir planlama yaklaşımı ile korunamamış ve kirletilmiştir. Kanalizasyon atıklarının dereye yönlendirilmesiyle kirlenen dere, Ankara'da beton menfezler içerisine alınan ilk dere olma özelliğini üstlenmiştir. Günümüzde beton menfezler içine alınan derenin üzerine inşa edilen yaklaşık 2,33 kilometre uzunluğunda ve 30 metre genişliğinde, toplam 6 şeritli Bentderesi Caddesi boyunca yoğun araç trafiği akmaktadır. Son zamanlarda geçirimsiz asfalt yüzeylerin artmasından ve bu 
geçirimsiz yüzeylerin dere yataklarında yer almasından dolayı ani seller meydana gelmektedir. Hem Bent Deresi hem de çevresi ekolojik fayda değerini kaybetmiştir.

Kentsel su planlamasında alınan yanlış kararlar Ankara kentinin doğal, kültürel ve mekânsal özelliklerini yitirmesine sebep olmuştur. Ulaşım ve çevre ilișkisi iyi kurgulanamamıș eș zamanlı olarak birbirine zarar veren iki kavram haline dönüştürülmüştür. Hızlı ve çarpık yapılaşmanın bir sonucu olarak dereler evsel ve sanayi atıklarıyla kirletilmektedir. Yağmur suyu ve evsel atık sular birbirlerinden ayrılmadığı gibi yağmur suyu Ankara kentinde toprağa karışamamaktadır. Kanalizasyon hattına dönüştürülüp yolların altında terk edilen dereler bir süre yer altından gitse bile sonunda Ankara Çayı'na dökülmektedir. Yer yer üzeri açık şekilde akan Ankara Çayı çevreye kötü kokular yaymakta ve salgın hastalıklar açısında da tehdit oluşturmaktadır. Kent estetiğini de olumsuz yönde etkilemektedir. Ankara için kentsel akarsular ulaşımda doğal bir eşik olarak görülmekte, bireylerin ulaşımda erișilebilirliğini kısıtlayıcı faktör olarak algılanmaktadır. Bir diğer yandan ulaşım hizmetlerini iyileştirmek için yapılan yollar, altgeçitler, raylı sistemler kapatılan dereler üzerine yapılmıştır. Kapalı kanalizasyon hatları ve beton menfezler içinde akan dereler ulaşım altyapısına da zarar vermektedir. Ulaşım altyapısında meydana gelen aksaklıklar gözle görülemedikçe büyümekte ve yollarda çökmelere sebep olmaktadır. Metro istasyonları sular altında kalmakta ulaşım sistemlerinde aksaklıklar meydana gelmektedir. Bu durumda ulaşım sistemlerinde hem altyapı hem üstyapı zarar görmekte, mal ve can kayıplarına sebep olmaktadır. Her sene aşırı yağışlar sonrası sel felaketi ve su baskını ihtimali, üzeri kapatılıp yol ve katlı kavşak yapılan eski dere yataklarında giderek artmaktadır. İklim değişikliği ve artan küresel ısınmanın etkilerini hafifletmek için kullanılabilecek bir değer olan dereler, üzeri kapatılarak kentsel ısının arttırılmasına sebep olmaktadır. Doğal olan dereler korunmak yerine kentte fiskiyeler ve yapay göller ile kentin su belleği yaşatılmaya çalışılmaktadır. Bunun yerine kentin kaybolan derelerini keşfedilmesi, tekrar gün yüzüne çıkarılması ve bugünkü ulaşım sistemleri ile birlikte düşünülerek akarsu restorasyon projelerinin gerçekleştirilmesi gerekmektedir. Kente temiz su sağlanmak, yeraltı su kaynaklarını iyileştirmek, kentsel ısınmayı azaltmak, biyolojik çeşitliliğin korunmasını sağlamak, gürültü ve hava kirliliğini azaltmak gibi ekolojik fayda değeri yüksek olan başarılı akarsu restorasyon projelerine daha fazla yer verilmelidir. Ayrıca kentsel ekosistemin destekleyicisi ve tamamlayıcısı olan mavi-yeşil koridorlara nehir restorasyon projeleri dahil edilmeli, planlama ve tasarımda kentsel gri altyapıyla da bağlantı kurulmalı ve kentsel yeşil altyapı, tüm bileşenleriyle birlikte koordine edilerek planlanmalıdır.

\section{KAYNAKÇA}

Atölye Çalışması. (2017). Ankara arazi kullanım haritası. Gazi Üniversitesi, Mimarlık Fakültesi Şehir ve Bölge Planlama Bölümü, 2017-2018 Güz Dönemi, ŞBP-461 Şehircilik Projesi VI, Ankara.

Benedict, M.A. and McMahon, E.T. (2002). Green infrastructure smart conservation for the 21 st century. Renewable Resources Journal, 20(3), 12-17.

Best Practice: Large-scale green space reclamation plan. (2012). New York City Global Partners. 26 Aralık 2019 tarihinde http://www.nyc.gov/html/ia/gprb/downloads/pdf/Madrid_MadridRioProject.pdf adresinden erişildi.

Chou, R. J. (2016). Achieving successful river restoration in dense urban areas: lessons from Taiwan. Sustainability Journal, 8(1159), 2-23.

Demir, A. ve Baylan, E. (2019). Van kent merkezi ve yakın çevresinde yeşil altyapı bileşenlerinin cbs araçları ile tanımlanması. Strategic Public Management Journal, 9, 79-108.

Gülçin, D. (2018). Yeşil altyapı bağlamında açık/yeşil alan sistemlerinin uygulama olanaklarının araştırılması: Așağı Büyük Menderes Havzası örneği. Yayımlanmamıș doktora tezi, Çukurova Üniversitesi, Fen Bilimleri Enstitüsü, Peyzaj Mimarlığı Anabilim Dalı, Adana. 
Güler, M. ve Turan, A. (2013). Türkiye'de sürdürülebilir kentsel gelişme stratejileri: KENTGES eylem planı (2010-2023) Örneği. Avrupa Ekonomileri Uluslararası Konferansında sunulan bildiri, Oturum 1B: Büyüme ve Gelişme (s.255-260) içinde. Beykent Üniversitesi, İstanbul.

Günel, G. ve Kılcı, A. (2015). Ankara şehri 1924 haritası: eski bir haritada Ankara'yı tanımak. Ankara Araştırma Dergisi, 3(1), 78-107.

Kaymaz, I. (2019). The lost streams of Ankara: a case study of bentderesi. IOP Conference Series: Materials Science and Engineering, 603(4), 1-7.

Kaynar, İ.S. (2017). Ankara'nın 11 eylül 1957 sel felaketi ve siyasi gündemi. Ankara Araştırma Dergisi, 5(2), 197-224.

KENTGES Eylem Planı (2010-2023). (2010).Çevre ve Şehircilik Bakanlığı, Ankara.

Kırkık Aydemir, P., Yılmazsoy, B.K. ve Turgay, T. (2018). Sürdürülebilir mimari ve yeşil tasarım ile kentsel yenileme. Ileri Teknoloji Bilimleri Dergisi, 7(1), 29-41.

Lepor1, F., Palm, D. and Malmqvist, B. (2005). Effects of stream restoration on ecosystem functioning: detritus retentiveness and decomposition. Journal of Applied Ecolog, 42, 228-238.

Mihçıŏlu Bilgi, E. (2010). The physıcal evolutıon of the historıc city of Ankara between 1839 and 1944: a morphological analysis. Unpublished doctoral thesis. METU, Graduate School of Natural and Applied Sciences, Ankara.

Pekin, U. (2007). Kentsel akarsu koridorlarının geliştirilmesi ve Ankara Çayı kavramsal yeşil yol planı. Yayımlanmamış doktora tezi, Ankara Üniversitesi, Fen Bilimleri Enstitüsü, Peyzaj Mimarlı̆̆ı Anabilim Dalı, Ankara.

Semiz, Y. (Yönetmen). (15 Kasım 2019). Asfaltın Altında Dereler Var Belgesel Galast. Luwi Film, Ankara İMO.

Palmer, M.A., Bernhardt, E.S., Allan, J. D., Lake, P.S., Alexander, G., Brooks, S., Carr, J., Clayton, S., Dahm, C. N., Follstad Shah, J., Galat, D. L., Loss, S. G., Goodwin, P., Hart, D.D., Hassett, B., Jenkınson, R., Kondolf, G.M., Lave, R., Meyer, J.L., O'donnell, T.K., Pagano L.E. and Sudduth. E. (2005). Standards for ecologically successful river restoration. Journal of Applied Ecolog, 42, 208-217.

Ryu, C. and Kwon, Y. (2016). How do mega projects alter the city to be more sustainable? Spatial changes following the seoul cheonggyecheon restoration project in South Korea. Sustainability Journal, 8(1178), 1-17.

Tapan Şilliler, D. ve Ceviz Sanalan, K. (Ed.). (2013). Yeşil altyapı Avrupa’nın doğal sermayesini geliş̧tirmek, Avrupa komisyonu bildirimi. Ankara: Doğa Koruma Merkezi.

Tunçer, M. (2013). Ankara'da 90 yılda yok olan doğal ve tarihsel / kültürel çevre: sorunlar-çözümler. Köroğlu, A. (Ed.). Başkent Oluşunu 90. Yllında Ankara:1923-2013 Sempozyumu, 7-8 Ekim 2013, Ankara, Türkiye, Bildiriler içinde (s.107-122). Ankara Üniversitesi Dil ve TarihCoğrafya Fakültesi.

URL 1: 8 Kasım 2019 tarihinde https://www.youtube.com/watch?v=bNU-CSHyibc adresinden erişildi.

URL 2: 9 Kasım 2019 tarihinde https://www.nadirkitap.com/yapi-mimari-gorunum-ankara-1960-70kartpostal-sihhiye-den-ulus-a-dogru-bir-bakis-ataturk-bulvari-efemera13773772.html adresinden erişildi.

URL 3: 8 Kasim 2019 tarihinde https://www.cayyolu.com.tr/cayyolu-nu-yagmur-vurdu/230346/ adresinden erişildi.

URL 4: 8 Kasım 2019 tarihinde http://www.ilgazetesi.com.tr/ankarada-yagis-sonrasi-alt-gecidi-su-basti$114753 \mathrm{~h} . \mathrm{htm}$ adresinden erişildi.

URL 5: https://www.egehaber.com/gundem/ankara-da-yagis-sele-donustu-hastaneyi-su-basti-cadde-

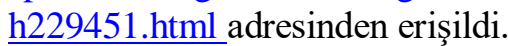


URL 6: http://www.milliyet.com.tr/gundem/yer-yarildi-16-5-saat-sonra-cesedi-cikti-1557507 adresinden erişildi.

URL 7: 12 Kasım 2019 tarihinde http://www.moblogankara.org/mimarlardan/2014/11/13/bir-mutlulukhikyesi-bentderesi adresinden erişildi.

URL 8: 8 Kasim 2019 tarihinde https://i.pinimg.com/originals/95/b7/a9/95b7a9dc3a0019d6daac90ca81c9d75a.jpg adresinden erişildi.

URL 9: 8 Kasım 2019 tarihinde http://ankaraarsivi.atilim.edu.tr/shares/ankara/images/imagebrowser/161.jpg adresinden erişildi.

URL 10: 8 Aralık 2019 tarihinde https://www.youtube.com/watch?v=gNO7eP4WbUU adresinden erişildi. 